\title{
O conhecimento do transporte ferroviario
}

1. O CONTRATO DE TRANSPORTE E O CODIGO DO COMERCIO. - Não legislou o código do comércio para o transporte por via de estradas de ferro. Desconhecia-o. Tratou, no capitulo sexto da parte primeira, dos condutores de generos e comissarios de transportes. Promulgado pela lei n. 556, de 22 de junho de 1850, só quatro anos depois, em 30 de abril de 1854, se inaugurou a primeira estrada de ferro brasileira: a de Mauá - da Imperial Companhia de Navegação e de Estrada de Ferro de Petropolis.

Fixou, entretanto, os principios mediante os quais se disciplinaria, mais tarde, o transporte ferroviario. Definiu as obrigações dos transportadores. Assegurou-lhes os direitos correspetivos.

Aos barqueiros, tropeiros e quaisquer outros condutores de generos, ou comissarios, que do seu transporte se encarrcgassem, mediante uma comissão, frete ou aluguel, impôs o art. 99 do codigo a obrigação de efetuar a sua entrega, fielmente, no tempo e no lugar ajustado. E a empregarem toda 
a diligencia e meios praticados pelas pessôas exatas no cumprimento dos seus deveres, em casos semelhantes, para a sua conservação. Como depositarios os considerou. Se lhes atribuiu a faculdade de fazer, por conta de quem pertencessem, as despesas necessarias para esse fim, responsabilizouos pelas perdas e danos resultantes de sua malversação ou omissão, ou de seus feitores, caixeiros ou quaisquer agentes.

Lançou, ademais, no art. 103, o salutar preceito de correrem por conta do condutor ou comissario de transportes as perdas ou avarias acontecidas ás fazendas, durante êle, não provindas de vicio proprio, força maior ou caso fortuito.

2. A CAUTELA OU RECIBO DOS GENEROS. - Estabelecendo um regime de responsabilidades, determinou o momento de seu começo: o do recebimento dos generos; e o de sua expiração: depois de efetuada a sua entrega.

Exigiu, pelo disposto no art. 100, a prova escrita do recebimento, pois no art. 105 preceituou não ser o condutor ou comissario de transporte responsavel senão pelos efeitos constantes da cautela ou recibo, que tiver assinado, sem admitir ao carregador a prova de ter entregue maior quantidade dos efeitos nele consignados, ou entre os designados acharem-se outros de maior valor.

Pingou, dessarte, os pontos nos is.

Tanto o carregador, esclareceu, como o condutor, devem exigir-se mutuamente uma cautela ou recibo, por duas vias, ou mais, se pedidas, contendo:

a) o nome dos donos dos generos ou carregador, o do condutor ou comissario de transporte e o da pessôa a quem são dirigidos e o lugar onde deva fazer-se a entrega;

b) a designação dos efeitos e a sua qualidade generica, peso ou numero dos volumes e as marcas ou outros sinais externos;

c) o frete ou aluguel do transporte;

d) o prazo dentro do qual deve efetuar-se a entega; 
e) tudo o mais que tiver entrado no ajuste.

Investia-se o transportador nos direitos e subrogava-se nas obrigações proprias dos depositarios. Negou-lhe o art. 114 ação para investigar se e porque os generos pertenciam, ou não, ao carregador ou consignatario, devendo fazer-lhes a entrega mediante a apresentação de titulo bastante: a cautela ou recibo. Não lhe era admitida oposição alguma, sob pena de responder pelos danos e riscos resultantes da móra e de contra ele proceder-se como depositario.

\section{II}

3. O REGULAMENTO DO TRANSPORTE FERROVIARIO. - Lançada a primeira locomotiva sobre os primeiros trilhos, as tentativas abriram o periodo das realisações em materia de transporte ferroviario.

Pelo dec. n. 1.664, de 27 de outubro de 1855, deu o governo imperial regulamento para a execução do de $n$. 816 , de 10 de julho de 1855 , sobre as desapropriações para a construção de obras e serviços das estradas de ferro, afim de facilitar-lhes o desenvolvimento e a irradiação. E, em virtude do $\S 14$ do art. 1 do dec. n. 641, de 26 de junho de 1852, aprovou o regulamento para a fiscalisação da segurança, conservação e policia das estradas de ferro.

Esses dois diplomas, com tanta segurança e lucidês concebidos e redigidos, trouxeram, sob a rubrica magestatica, a assinatura de Luiz Pedreira do Couto Ferraz, mais tarde lente catedratico da Faculdade de Direito de São Paulo, o Visconde do Bom Retiro, que tantos e assinalados serviços prestou ao paiz.

4. O CONHECIMENTO DA CARGA. - No capitulo do trafego e cobrança das taxas, cuidou da disciplina da carga. Substituiu a cautela ou recibo dos generos, dando-lhe outro feitio e outra denominação: a do congenere do transporte 
maritimo, cujos requisitos o art. 575 do codigo do comercio enumerou:

a) o nome do capitão e do carregador ou consignatario, podendo omitir-se o nome deste, se fôr á ordem;

b) a qualidade e quantidade dos objetos da carga e numeros anotados á margem;

c) o lugar da partida e do destino, com declaração das escalas, se houver;

d) o preço do frete e primagem, se esta fôr estipulada, e o lugar do pagamento;

e) a assinatura do capitão e do carregador.

Ordenara o art. 113 do regulamento das cargas recebidas se expedisse um conhecimento de talão, cujo numero seria lançado com tinta, em cada volume, no ato do necebimento. Abrangeria cada talão as cargas remetidas de uma vês por uma só pessôa a outra, ou uma só firma comercial.

E a entrega, no art. 113 ficara exarado, se faria mediante restituição do conhecimento, o qual, inutilisado por um carimbo na estação, que tivesse feito a entrega, seria devolvido á remetente da carga.

Fixando essa nórma, abriu-lhe, todavia, uma exceção. Previra, no art. 114, a falta do conhecimento. Nesse caso, poderia a pessôa, a quem fossem enviadas as cargas, verificada a sua identidade, a contento da administração, retiralas, passando recibo em um livro de talão. Este recibo, acentuara o texto, substituiria o conhecimento, que ficaria, por ele, anulado.

Mais não disse quanto ao conhecimento, senão o suficiente para precisar a responsabilidade da companhia ou empreza pelas cargas entregues sem recibo, pelo valor real e imediato dos volumes extraviados e não em razão dos lucros da sua entrega esperados.

Não lhe indicou os requisitos. Não lhe atribuiu a força de escritura publica, que o codigo conferiu ao maritimo, 
como tal acionavel. Tão pouco preceituou se poderia ser passado á ordem e, então, transferir-se e negociar-se por via do endosso.

\section{A NATUREZA JURIDICA DO CONHECIMENTO. -}

De tal modo conceituado, era simples documento comprobatorio do despacho da mercadoria. Provava o seu embarque. Importava na obrigação da restitui-la, oriunda do fato do seu recebimento. Podia o cumprimento desta ser exigido mesmo sem a apresentação dele: em caso de extravio, bastava ao consignatario, na estação de destino, provar a sua identidade, afim de retira-la, mediante recibo, que tornaria o conhecimento inutil.

A pouca extensão das estradas de ferro tornava o transporte rapido. A duração do conhecimento era, por isso, efemera. A primitividade de nossa organisação comercial e bancaria, por outro lado, não lhe reclamava a negociabilidade. Não podia servir de lastro para operações de credito. Não representava as mercadorias, nele descriminadas. Podiam ser retiradas das estações, mediante simples recibo, e penhoradas ou embargadas por dividas do seu proprietario, sem que a sua transferencia lhes afetasse a propriedade. Não era essencial ao contrato de transporte. Existia este mesmo sem documento escrito. Podia ser provado por testemunhas, quando o valor da carga não excedesse á taxa legal

Com o correr dos tempos, entretanto, as estradas de ferro foram alongando o seu trafego, nas suas avançadas de penetração pelo territorio brasileiro. $\mathrm{O}$ comercio, ao mes-

(1) A provia de testemunhas, fóra dos casos expressamente declarados no codigo do comercio - preceitua este no art. 123 só é admissivel em juizo comercial nos contratos cujo valor não exceder a $400 \$ 000$.

Em transações de maior quantia, a prova testemunhal somente será admitida como subsidiaria de outras provas por escrito. 
mo passo, se foi alastrando e creando necessidades e praticas de que antes se não cogitara.

E o conhecimento do transporte terrestre passou a ser negociado, por via de endosso.

Admitiu-se a legitimidade dessa operação, pelo argumento por INGLEZ DE Souza desenvolvido:

"Sendo permitidas as obrigações ao portador que não exprimam promessa de pagamento em dinheiro, nenhuma razão ha para condenar os conhecimentos á ordem ou ao portador nos transportes terrestres. Aliás já em escala consideravel estão em uso entre nós.

E levou além as suas conclusões. Entendeu transferir o conhecimento ao portador, pela tradição, a posse das mercadorias transportadas, aplicando-se-lhe os principios estabelecidos para o conhecimento maritimo, no que não fossem contrarios á indole do transporte terrestre.

6. O CONHECIMENTO E A LEI FALIMENTAR. Enumerando os titulos, que considerou obrigações liquidas e certas, e cuja falta de cumprimento caracterizaria a falencia, entre eles incluiu a lei n. 2.024, de 17 de dezembro de 1908, art. 1, $\S$ unico, n. VI, "o conhecimento de frete". Não fez referencia especial ao maritimo. Nem ao terrestre. Incluir-se-ia na generalidade da disposição o do transporte ferroviario?

Ao parecer de J. X. Carvalho de Mendonça, não. O texto aludia, precisamente, ao maritimo. E isso, anotara, por ter força de escritura publica somente o passado nos termos do art. 575 do codigo comercial. Do ferroviario não cogitara (3).

(2) H. Inglez de Souza, Titulos ao portador no direito brusiieiro, pag. 428, ns. 564 e 566 .

(3) J. X. Canvalho de Mendonga, Tratado de Direito Comercial Brasileiro, vol. 7, pag. 231, n. 166-K, e Das Falencias e dos meios preventivos de sua declaração, vol. 1, pag. 68, em nota. 
Como, em falta de disposição legal, atribuir-lhe a força de escritura publica? Como, em tais condições, reconhecerlhe liquidês e certeza?

Manteve o dec. n. 5.746, de 9 de dezembro de 1929, o texto, com a mesma redação.

Posto haja considerado plausivel estender a locução conhecimento de frete ao do transporte por terra ou por agua, rendeu-se um de seus comentadores á evidencia:

"Quando o fretamento é total, ou parcial do primeiro modo, isto é, de certa parte do navio (codigo comercial, art. $567, \mathrm{n} .3$, in fine), o respetivo instrumento de contrato chama-se carta-partida, carta de fretamento, ou apolice de fr'ttamento. Quando parcial do segundo modo, isto é, consistente no recebimento da carga a bordo para ser transportada, diz-se conhecimento de frete, apolice de carregamento, ou letra de cambio do mar.

E', pois, exatamente a esta segunda qualidade de titulos que alude a alinea VI do $\S$ unico do art. 1 da lei; ao titulo documentario do contrato de fretamento parcial, que consiste no recebimento do objeto a bordo e seu transporte. Ha outras especies tambem denominadas conhecimentos, como o ferroviario; porém, aquela chamada propriamente conhecimento de frete é o relativo ao contrato de fretamento regido pelo direito maritimo" (4).

Nem de outro modo podia ser, em razão da propria natureza do conhecimento ferroviario.

\section{III}

7. O REGULAMENTO GERAL DOS TRANSPORTES. - No intuito de obviar dificuldades, surgidas da pratica da transferencia do conhecimento, cuidaram as emprezas de estradas de ferro de regulamenta-la. Como a contribuição

(4) Paulo de Lacehda, Da Falencia no Direito Brasileiro, pag. 136, ns. 187 e 188 . 
legislativa seria morosa, apelaram para o poder executivo, o em que, no regimen presidencial, se fundem todos os poderes.

Elaboraram um regulamento geral dos transportes as do Estado de São Paulo. Elaboraram-no e submeteram-no á aprovação do Governo do Estado. Aprovou este o regulamento dos transportes e do telegrafo, que de então em diante vigoraria nas estradas de ferro Funilense, Araraquara, Dourado, Ramal Ferreo Campineiro, Itatibense, S. Paulo e Goiás e nas linhas de concessão estadual das companhias Paulista, Mogiana, Sorocabana e S. Paulo Railway. Aprovou-o pelo dec. 2.312, de 21 de novembro de 1912, assinado pelo presidente do Estado, Francisco de Paula Rodrigues Alves, e referendado pelo secretario da agricultura, comercio e obras publicas, Paulo de Moraes Barros.

Tambem o aprovou o Governo da Republica, pelo dec. n. 10.204, de 30 de abril de 1913, expedido pelo presidente, Marechal Hermes R. da Fonseca, referendado pelo ministro da Viação, Jose' Barbosa Gonçalves, afim de vigorar nas linhas de concessão federal das mesmas estradas de ferro paulistas.

Minuciosamente estudaram o contrato de transportes em suas varias modalidades, num autentico regimento interno, em regulamento geral transmudado.

No concernente ao transporte de coisas, tratou:

a) da bagagem, ou seja dos objetos de uso pessoal dos viajantes, ou destinados a prover ás necessidades ou condições da viagem (arts. 27 a 39);

b) da encomenda, especial aos generos de rapida deterioração por ação do tempo, no art. 43 mencionados (aboboras; agua potavel ou do mar, até o peso de 100 quilos; aipim; caças mortas; cana de assucar ou caldo de cana, até o peso de 20 quilos por despacho; carás; carnes verdes ou frescas; coalhada; creme de leite; curáu; doces frescos em bandeja, para festas; empadas; fressuras; frutas frescas ou verdes; gelo; hortaliças e legumes verdes ou frescos; leite fresco; 
linguas frescas; mandioca; manteiga fresca; milho verde; miudo de rêses; mocotós frescos; nata; ovos; pamonha; pão; peixe fresco; requeijão fresco; rins frescos; sorvetes; toucinho fresco; tripas frescas) e transportaveis em trens de passageiros e mixtos (arts. 40 a 47);

c) de volumes expressos, para a entrega a domicilio, quando destinados ás principais estações ou a outras em trafego mutuo, volumes de encomenda cujo peso ou dimensões não excedam de 30 quilos ou 200 decimetros cubicos, compreendidos os pequenos animais e as aves domesticas ou silvestres, devidamente acondicionadas (art. 48);

d) de mercadorias (arts. 69 a 95);

e) de volumes vasios (art. 96);

f) de veiculos (arts. 97 a 99).

Outros regulamentos, posteriormente, foram aprovados. Assim, atendendo a proposta da Inspetoria Federal das Estradas e tendo em vista o acôrdo por ela celebrado com o governo do Estado do Rio de Janeiro e The Leopoldina Railway Company, para a adoção de medidas provisorias, necessarias e urgentes, para minorar, em curto prazo, a crise dos transportes nas linhas de concessão federal, o governo federal, pelo dec. n. 15.624, de 24 de agosto de 1922, aprovou o regulamento de transportes e do telegrafo para as linhas federais e fluminenses daquela empreza ferroviaria.

Pouco depois, e pelo decr. n. 15.673, de 7 de setembro de 1922, o presidente Epitacio Pessoa aprovou o regulamento para segurança, policia e trafego das estradas de ferro, assinado por J. Preses do Rro, ministro da Viação e Obras Publicas.

Uniformizou-se, de certo modo, o serviço de fiscalização das estradas de ferro, subordinando todas ao mesmo regulamento, em que se consolidaram as disposições no de cada empreza contidas, com pequenas variantes.

Não obstante, e deferindo o requerido pelas companhias São Paulo Railway Co. Ltd. e a Estrada de Ferro Sorocabana, 
o presidente Washington Luis, pelo decr. n. 17.775 , de 16 de abril de 1927, modificou o regulamento geral aprovadu pelo decr. n. 10.204, de 30 de abril de 1913, afim de mandar acrescer ao seu art. 88 o seguinte paragrafo:

"O café despachado com frete pago ou a pagar, em quantidade superior a seis sacas, só será entregue á vista do conhecimento original.

No caso de perda ou extravio do conhecimento, a entrega se fará por mandado judicial, ou, depois de publicada a perda ou extravio, pelo consignatario, durante dez dias no Diario Oficial do Estado de São Paulo e em dois jornais de larga circulação, sem reclamação ou protesto, mediante segunda via do conhecimento ou recibo, na fórma do $\S 2$ ".

Uma medida de emergencia, especialissima para os conhecimentos de despacho de café, vigorante apenas no Estado de S. Paulo, mas que lhes não conferia estrutura juridica substancial diversa da que, até então, apresentavam.

Por seu turno, o presidente do Estado, Carlos de Campos, pelo decr. n. 4.173, de 15 de janeiro de 1927, já havia incorporado ao art. 88 do regulamento geral de transportes, aprovado pelo decr. n. 2.312 , de 21 de novembro de 1912, o mesmo paragrafo.

\section{O PROCESSO DO DESPACHO DE MERCADORIAS.} - A entrega das mercadorias, afim de serem submetidas a despacho, deve ser acompanhada de uma relação escrita: a nota de expedição, com os seguintes requisitos:

a) a data da apresentação;

b) o nome e a residencia do expedidor e do destinatario;

c) o numero de volumes, natureza e peso bruto;

d) o acondicionamento e a marca.

A nota de expedição, tambem chamada - nota de consignação, será assinada pelo expedidor, e a assinatura impressa ou autografada. 
Entendendo por expedição um ou mais volumes procedentes de um só expedidor e endereçados a um só consignatario, acentuou o regulamento constituir cada nota uma expedição, não podendo mencionar senão o nome de um consignatario.

Verificada a exatidão da nota de expedição - salvo o caso do carregamento ser efetuado pelo proprio remetente, quando concessionario de desvio particular - a estação despachante fará a inscrição da mercadoria, dando ao remetente um conhecimento, exigivel na estação de destino por ocasião da entrega dos objetos, sem embargo da entrega poder realizar-se por via de recibo, em substituição do conhecimento não apresentado, ao consignatario ou pessôa por ele legalmente autorisada, depois de reconhecida a sua identidade.

Permitiu, expressamente, a tirada do conhecimento á ordem e adotou, nos arts. 81 e 88 , a regra de ser o seu endosso, nesse caso, e somente nele, permitido:

"O endosso do conhecimento só é permitido nos despachos á ordem".

\section{A CLAUSULA “A' ORDEM" NO CONHECIMENTO} FERROVIARIO. - Introduziu o regulamento geral dos transportes, em tais condições, preceito de ordem substantiva, que vinha alterar a natureza do conhecimento ferroviario.

No conhecimento maritimo, era possivel omitir-se o nome do consignatario, e substitui-lo pela clausula "á ordem", por efeito de lei: permite-o, expressamente, o art. 575 do codigo do comercio.

Aparentou-se, dessarte, a legalidade da usança e a sua pratica se não interrompeu.

Não se resolveu, nem podia ter-se resolvido a controversia, desde então posta em debate.

A maneira por via da qual se transmitem cousas e direitos é pela cessão. Ceder é transferir a propriedade, mediante o pagamento de preço ajustado, de cousa ou de di- 
reitos. Tambem o é o endosso, instituto especialissimo aos titulos de credito e valido somente nos casos permitidos em lei.

Onde a que permitiu o endosso do conhecimento ferroviario?

Teria ele, assim, por efeito operar a transferencia das mercadorias nele descriminadas?

Ficou aberta a questão em doutrina e, por isso mesmo, em jurisprudencia.

\section{IV}

10. O ENDOSSO DO CONHECIMENTO FERROVIARIO. - A chamada politica da valorisação do café e a sua retenção nos armazens reguladores de sua distribuição e de sua entrada no porto de Santos, foi de inesperadas consequencias para a vida economica de São Paulo e, por via reflexa, do Brasil.

Bem poucos lavradores vendiam as suas colheitas "na porta", isto é, nas proprias fazendas, entregues embarcadas nas estradas de ferro. Quasi todos enviavam os seus cafés para Santos, consignados a casas comissarias de venda. Estas os recebiam, misturavam, batiam, selecionavam, ensacavam de novo e os vendiam, prestando as suas contas de venda.

Para isso, entretanto, faziam aos fazendeiros os necessarios adiantamentos, mediante saques de letras de cambio, que descontavam nos bancos locais ou da zona, e elas aceitavam, a trinta dias de data, em regra.

Eram os comissarios verdadeiros banqueiros dos fazendeiros.

A retenção dos cafés nos armazens reguladores interiores, os chamados "cemiterios", e a regularisação de sua entrada em Santos, permitida em quotas a cada fazendeiro, na proporção das probabilidades das colheitas de cada safra., mudou a situação. Premidos pelas circunstancias, os co- 
missarios, de posse dos conhecimentos de cafés que demoradamente chegariam, se viram na contingencia de levantar os fundos necessarios para o giro dos seus negocios e para os adiantamentos aos seus comitentes. Mas os bancos lhes exigiram garantias reais. Todos, então, caucionaram-lhes os conhecimentos de seus comitentes, como se seus fossem.

Desvirtuou-se a função dos comissarios: de comissarios de venda passaram a comissarios de caução e, peior, ainda, de caução em garantia dos seus proprios negocios. E a caução se fez de conhecimentos á ordem e de conhecimentos nominativos, mesmo quando endossados com a declaração expressa de "em consignação" (5).

(5) A proposito, proferiu a Quarta Camara do Tribunal de Justiça de São Paulo interessante acórdão, que foi publicado no Diario da Justiça, de 7 de outubro de 1931, ano I, n. 214, pag. 10:

"Acórdão em Quarta Camara do Tribunal de Justiça, negar provimento ao recurso e confirmar a sentença recorrida. Custas pelo agravante. O agravado, fazendeiro em São José do Rio Pardo, enviou em consignação de venda á Companhia Comissaria Paulista, sociedade anonima com séde em Santos, 2.866 sacas de cafés despachadas numa estação da Estrada de Ferro Mogiana. Tendo sido decretada a falencia daquela Companhia, promoveu o agravado, contra a massa falida, uma reclamação reivindicatoria das partidas de café, em especie as já entradas e em armazem, e as ainda não chegadas nos seus respectivos conbecimentos. Informou a falida serem verdadeiras as alegações do reivindicante. Acrescentou que os conhecimentos referentes ao café haviam sido por ela caucionados em varios estabelecimentos bancarios. O síndico, porém, embargou a reivindicatoria, sustentando que os bancos têm, no caso, o direito de retenção assegurado no decreto numero 19.473 , de 10 de dezembro de 1930 , e que a reclamação deverá ser julgada procedente em parte, para ser entregue ao reivindicante o valor equivalente ao café. $\mathrm{Pe}-$ rito nomeado pelo Dr. Juiz de Direito examinou os conhecimentos em poder do Banco do Estado de S. Paulo, ora agravante, e do Banco do Brasil. No verso nos que se acham com o A., notou o endosso: "Em consignação - Oliveiros Dias Pinheiros"; e no do que se encontra com o Banco do Brasil observou que a assinatura está isolada, embora pareça que o remetente escrevera alguma coisa mais pouco acima de sua assinatura, onde ha uma ou algumas palavras canceladas a maquina de modo a não ser possivel ler o que se achava 
0 fracasso do plano de valorisação, entretanto, ocasionou varias falencias e concordatas preventivas de comissarios e, então, a controversia juridica sobre a validade do endosso teve a mais viva discussão.

\section{O ENDOSSO DO CONHECIMENTO E OS SEUS} EFEITOS. - Que o conhecimento não representava as mercadorias por via dele despachadas, de tal sorte que a sua transferencia na da propriedade destas importasse, constava já de um ato legislativo, em termos sugestivos.

escrito. $0 \mathrm{dr}$. Juiz de Direito considerou nula e inoperante a caução de conhecimento com a clausula "em consignação". Sabendo o credor caucionario que o objeto da caução não pertence ao devedor caucionante, falta-lhe o requisito de boa fé, exigido pelo art. 93, paragrafo $3 .^{\circ}$ da lei de falencias. Determinou, assim, que os conhecimentos contendo a clausula "em consignação" devem ser restituidos em especie, e que, quanto aos demais, o reivindicante tem direito apenas ao valor da mercadoria, depois de arbitrado. O Banco do Estado de São Paulo interpoz agravo dessa decisão, com fundamento no art. 139 , paragrafo $4 .^{\circ}$ da lei de falencias. Sustenta, na minuta do recurso, que a decisão agravada infringe aquela lei, art. 93, paragrafos 1 e 3 , bem como o decreto n. ${ }^{\circ} 19.473$, de 10 de dezembro de 1930 , arts. 4 e 8, devendo ser dado provimento ao recurso para ordenar-se a reivindicação tão somente do valor dos cafés reclamados, ficando com o agravante os conhecimentos que the foram caucionados pela falida. Decide o Tribunal, por votação unanime, que é de confirmar-se a sentença. $O$ endosso nos conhecimentos foi feito anteriormente ao decreto $n .^{\circ} 19.473$, cujo art. $4 .^{\circ}$, paragrafo unico, admite o endosso pignoraticio. Antes deste decreto os efeitos do endosso, em nossa legislação, limitavam-se a transferir a propriedade de titulos de credito ou a conferir mandato para sua cobrança. Não podiam, então, por não serem titulos de credito, servir de caução, mediante endosso, os conhecimentos ferroviarios, meros documentos probatorios do contrato de transporte.

O citado decreto não se aplica retroativamente a endossos anteriores á sua vigencia. Não tem semelhante alcance o disposto em seu art. 11, paragrafo unico, que não cuida de dar validade a contratos nulos pela legislação que o precedeu. Entretanto, o mesmo decreto só admite a clausula de penhor ou garantia quando expressa; e tal não ocorre com os conhecimentos em questão, nos quais não se 
Presumindo a culpa das estradas de ferro pela perda total ou parcial, furto ou avaria das mercadorias, que receberem para transportar, o decreto legislativo, n. 2.681, de 7 de dezembro de 1912, assim dispôs no art. 10:

"As ações judiciais oriundas do contrato de transporte por estrada de ferro por motivo de perda ou avaria, poderão ser intentadas pelos que tiverem recebido a mercadoria ou tenham direito a recebe-la, seus herdeiros o cessionarios. Para a ação ser intentada pelo remetente, seus herdeiros ou cessionarios deverão apresentar as duas vias da nota da expedição, nos casos em que elas são exigidas, ou autorisação do destinatario".

Deveria a lei, se o conhecimento tivesse a função de representar a mercadoria, exigir a sua apresentação, afim de justificar o legitimo interesse do proponente da ação. Não exigiu. Abstraiu dele. Contentou-se com a apresentação das notas de expedição ou com a autorisação do destinatario. $\mathrm{E}$ isso não seria admissivel se o conhecimento tivesse a importancia que se lhe atribuiu.

Mereceu as censuras de Cunha Gonçalves a redação do årt. 374 do codigo comercial português, segundo o qual "se a guia fôr á ordem ou ao portador, o endosso ou a tradição dela transferirá a propriedade dos objetos transportados"

$\mathrm{E}$ assim se exprimiu :

"Em qualquer dos casos, a transmissão da guia importa a transferencia da propriedade dos objetos transportados,

nota clausula alguma expressa a respeito. A clausula que neles se lê signiflca mandato, sem o efeito de transferir a propriedade da mercadoria. Quanto ao direito de retenção, tambem invocado pelo agravante, é inexistente, no caso, por lhe faltarem requisitos essenciais, exigidos pelo art. 93, paragrafo $3 .^{\circ}$ da lei de falencias: a) o agravante funda seu direito na posse de conhecimentos, e não na do café a que eles se referem; b) o agravante, deante do endosso-mandato, não podia atribuir á casa comissaria a propriedade do café; c) o agravante sabia, pela redaçãn do endosso, que o café pertencia ao agravado. São Paulo, 28 de setembro de 1931. - SYLVIO PORTUGAL, P. e relator - MARIO MASAGÃO - ABEILARD PIRES." 
como dispõe o art. 374, em que o legislador, mais uma vês, traduziu mal o codigo italiano, art. 392, al. 2. ${ }^{a}$, que apenas se refere á transferencia da disponibilidade, o que não é a mesma cousa.

Com efeito, o transporte tem por fim transferir materialmente a cousa transportada de um lugar a outro, e năo o de transmitir juridicamente a propriedade ou posse dela de uma a outra pessôa, o que depende do contrato que precedeu a expedição. Ora, sendo certo que tanto o expedidor como o destinatario, podem ser mandatarios de terceiros, ou que entre os dois póde não ter havido um contrato de compra e venda, ou doação, mas sim o de consignação, deposito, aluguer, penhor, etc., claro é que a transmissão da guia só póde importar, em muitos casos, a transmissão da disponibilidade, ou seja, da propriedade aparente ou material, do direito de receber do transportador a cousa transportada".

E concluiu:

"Portanto, quem não fôr, juridicamente, legitimo proprietario da cousa, não poderá, evidentemente, transferir a propriedade dela por simples transmissão da guia do transporte" (6).

Sustentou identica doutrina, J. X. Carvalho de MenDONÇA :

"O transporte nenhuma influencia exerce sobre a condição juridica das mercadorias, e sobre os direitos reais de propriedade, goso ou garantia que possam existir relativamente a terceiros. O contrato de transporte é negocio economico e juridico de carater transeunte e precario" (7).

Em falta de disposição identica, em nosso sistema legislativo, á do codigo comercial português, outra, em verdade, não podia ser a doutrina.

(6) Luiz da Cunha Gonçalves, Comentario ao Codigo Comercial Português, vol. 2, pag. 413, n. 560.

(7) J. X. Carvalho de Mendonça, Tratado de Direito Comercial Brasileiro, vol. 6, 2." parte, pag. 507, n. 1.103 . 
A transferencia do conhecimento, ainda que emitido com a clausula á ordem, não operava a transferencia da propriedade da mercadoria, que podia ser penhorada ou sequestrada por dividas do seu proprietario.

Foi o que fizeram operarios agricolas para se pagarem dos seus salarios. Promoveram o arresto, em armazens reguladores de Ribeirão Preto, de cafés pertencentes ao seu patrão. Convertido o arresto em penhora, embargada sob o fundamento de não pertencer a cousa penhorada ao executado, em razão do endosso dos respetivos conhecimentos, manteve-a a sentença de primeira instancia:

"Em face do direito constituido, o conhecimento de estradas de ferro representa apenas um contrato de transporte de mercadorias.

O simples endosso do conhecimento a um comissario ou o fato de haver sido o café consignado a comissario não constitue prova de alienação do mesmo café, feita pelo remetente ou pelo comitente ao endossatario ou ao comissario :

a) no primeiro caso, o endosso pode indicar que as mercadorias a que o conhecimento se refere foram apenas dadas em garantia ao comissario, como é de praxe em nosso Estado. Ora, neste caso, as mercadorias não foram alienadas pelo fazendeiro; estão apenas garantindo um debito seu. Podem, portanto, ser penhoradas ou arrestadas e o seu produto ser sujeito a concurso de credores.

b) no segundo caso, como é tambem de praxe, o comissario retira o café a ele consignado - ou mesmo constante de conhecimentos endossados - e o vende por conta do comitente, cobrando apenas uma comissão.

Em ambos os casos, pelo endosso ou pela consignação, não deixou o fazendeiro de ser proprietario da mercadoria desppachada; assim simples consignação de café a um comissario, como no caso em especie, não é prova plena, absoluta de venda e compra, ainda que aquele seja credor do comitente por titulos ou em conta corrente. E os nossos 
usos comerciais confirmam, a respeito, essa asserção, pois mesmo sendo credor do comitente, o comissario vende o café por aquele, desconta as despezas e a comissão e leva o liquido da conta de venda a credito de seu devedor" (8).

Esta doutrina foi consagrada pelo Tribunal de Justiça de São Paulo em varios acórdãos, entre os quais:

a) o de 29 de setembro de 1930:

“. . os conhecimentos ferroviarios, apenas documentos probatorios, que são, do contrato de transporte, e não titulos de credito, não estão compreendidos entre os titulos que, conforme o art. 273 do codigo comercial, podem ser dados em penhor. $\mathrm{E}$ caucionados eles, mas não recebida a mercadoria a que se referem, nada obsta a restituição desta em especie.

Não colhe o argumento de que no mandato de venda que tem o comissario e efetuada ela, a reivindicação é do preço e não da mercadoria, que, alienada, não existe na posse do comissario: não é assim em se tratando de cousa não entregue, como na hipotese".

b) o de 16 de outubro de 1930:

“A caução dos conhecimentos não era valida, certo que não compreendidos entre os titulos que podem dar-se em penhor, conforme o art. 273 do codigo comercial, não são os conhecimentos ferroviarios caucionaveis: não são titulos de credito transferiveis, e nenhuma disposição legal os equipara aos que podem ser oferecidos em garantia".

c) o de 27 de outubro de 1930 :

"Trata-se, no caso, de um contrato de comissão de venda de cafés remetidos á casa comissaria dos agravantes. Caucionados por eles os conhecimentos ferroviarios a terceiros e sem autorisação do agravado, estão os agravantes obrigados á restituição da mercadoria ao comitente, ou, na falta desta, é pago o respetivo valor, consoante o art. 143

(8) Revista dos Tribunais, vol. 75, pag. 200. 
da lei de falencias. $O$ comitente nada tem com a caução feita pelos agravantes".

d) o de 24 de novembro de 1930:

"Alegou-se que os caucionarios estão na posse dos conhecimentos ferroviarios e recebidos por via de endosso. Mas tais conhecimentos têm a função apenas probatoria do contrato de transporte: não podem ser considerados nem titulo de credito e nem ao portador.

Como diz C. DE Mendonça, não têm o apoio legal, para que possam representar titulos de mercadorias.

Dos autos, além do mais, não consta a existencia dos referidos conhecimentos ferroviarios endossados. Nenhum dos interessados os juntou, para se poder ajuizar do seu valor. Ninguem tambem alegou a existencia de qualquer endosso, com a clausula de valor recebido. Admita-se, entretanto, a hipotese do endosso em branco em tais conhecimentos caucionados, mesmo assim força não tinha para passar a propriedade dos cafés aos réus; valeria apenas como simples mandato, por ser a mercadoria do autor reivindicante" (9).

Sem embargo; força é pôr em linha, esta doutrina não era pacifica.

Muito antes, em parecer datado de 20 de novembro de 1925, Edgardo de Castro Rebello, professor da Universidade do Rio de Janeiro, já se havia manifestado em sentido contrario:

"Consignando mercadorias á empresa de estrada de ferro para que lhes faça o transporte e dela recebendo 0 conhecimento, o expedidor perde temporariamente, por força das obrigações contraidas por uma e por outra parte, a posse direta da cousa, mas continua a, não só poder dispor das mercadorias expedidas, mediante giro do conhecimento, como a poder, mediante sua restituição, reave-las.

(9) Revista dos Tribunais, vol. 76, pag. 336 a 340 . 
Conserva, portanto, a posse indireta das mercadorias expedidas, porque posse é o exercicio, de fato, pleno, ou não, de algum dos poderes inerentes ao dominio, ou propriedade, entre os quais estão o de dispôr da cousa e o de rehavela (codigo civil, arts. 485, 486 e 524). Pelo endosso do conhecimento, o endossante transfere esses poderes ao endossatario que, por sua vês, tanto póde, mediante novo giro, dispôr das mercadorias que ele representa, como conservando-o comsigo, será somente quem poderá, findo o transporte, mediante sua devolução, obter a entrega das mercadorias. Pelo endosso do conhecimento adquire, portanto, o endossatario o dominio e a posse da cousa.

Fim predominante do conhecimento é "habilitar o destinatario ou o endossatario á livre disposição da mercadoria"; emitido, por conseguinte, o conhecimento, o condutor detem a cousa pelo possuidor legitimo; sua situação é a mesma do depositario (codigo comercial, art. 114; decr. n. 737 , de 1850, art. 280); adquirindo o titulo, adquire o endossatario "a posse da mercadoria, os direitos ulteriores que se relacionam com ela" (RAmella, La vendita nel moderno diritto, II, n. 410) (10).

Com outros argumentos, defendeu Raul Fernandes o mesmo ponto de vista, tambem em parecer, datado de 19 de novembro de 1930:

“A cessibilidade do conhecimento é fóra de qualquer duvida; mas as legislações variam no tocante ás facilidades da circulação desse documento.

Algumas prescrevem que os conhecimentos sejam nominativos. Outras, como a argentina (cod. com., art. 166) e a italiana (cod. do com, art. 392) permitem os conhecimentos á ordem ou ao portador.

A este segundo sistema se filia a legislação patria. De fato, o já citado decr. n. 10.204, de 30 de abril de 1913 (regulamento dos transportes nas estradas de ferro de conces-

(10) Revista de Direito, vol. 79, pag. 67. 
são federal em São Paulo) permite os despachos á ordem (art. 88). O dec. n. 10.826, de 23 de junho de 1913, estendeu o mesmo regulamento á Estrada de Ferro Central do Brasil. Os despachos á ordem praticados tambem nas estradas subordinadas á Contadoria Central Ferroviaria, e pode mesmo dizer-se que nessas estradas se admite o conhecimento ao portador, se bem que o respetivo regulamento exija a menção do destinatario nas notas da expedição, por outro lado prescreve que "a estrada considerará como consignatario quem apresentar o conhecimento do despacho, não sendo obrigada a verificar a sua identidade, nem responsavel por entrega indevida feita á vista do conhecimento" (art. 70).

De um modo ou de outro, é indubitavel que os conhecimentos são cessiveis, e que pela cessão o consignatario das mercadorias pode transferir a terceiro o direito de as receber no ponto de destino. A diferença é que os conhecimentos á ordem ou ao portador circulam com extrema facilidade, os primeiros pelo endosso e os segundos pela tradição manual, ao passo que a cessão dos conhecimentos nominativos requer contrato em fórma ordinaria.

Nessas condições, a caução de conhecimento ferroviario é operação perfeitamente licita, não como caução de titulo de credito, natureza que não tem esse documento, mas como complemento de um contrato de penhor, cujo objeto é a propria mercadoria representada pelo conhecimento, ou um direito creditorio a que ela serve de garantia.

$O$ codigo comercial permite a tradição da coisa apenhada pelo modo que estiver em uso no lugar onde se achar depositada (arts. 199 e 274) ; e o uso em relação ás mercadorias despachadas nas estradas de ferro, principalmente o café, nas principais praças do Brasil, é o devedor pignoraticio entrega-las mediante caução dos conhecimentos.

Em suma:

Os emprestimos sobre garantia de cafés despachados nas estradas de ferro são emprestimos pignoraticios, nos quais o objeto do penhor é a mercadoria e não o conhecimento 
ferroviario caucionado. A tradição do penhor para o poder do credor, requisito essencial do contrato, é que se opera, de acôrdo com o uso, pela caução dos conhecimentos. Tais contratos pignoraticios se autorisam formalmente com as disposições dos arts. 272,273 e 274 do codigo comercial e 768 do codigo civil.

Ainda que a lei não autorisasse expressamente, na forma em que eles vêm sendo feitos, e graças á qual se mobilisaram para credito á lavoura centenas de milhares de contos, seria caso de sanciona-los o direito pretoriano, consagrando destarte o uso radicado nas praças do Rio, Santos e Vitoria.

A solução contraria irrogaria perda iniqua das garantias aceitas de bôa fé pelos prestadores de capitais á lavoura e, em ultima analise, seria em detrimento desta, estancando-lhe essa fonte de credito" (11).

\section{V}

12. A LEGISLAÇÃO DITATORIAL SOBRE OS CONHECIMENTOS DE TRANSPORTES. -- A orientação seguida pela jurisprudencia do Tribunal de Justiça de São Paulo, a unica compativel com a disciplina legislativa da materia, causou sensação no cosmos mercantil e bancario. Nem sempre comerciantes e banqueiros consultam a lei para a realisação dos seus negocios, sem embargo de terem quasi todos consultores juridicos de nomeada. Celebram-nos, mesmo, sem ouvir-lhes o parecer.

Foi o que aconteceu.

Nessa emergencia, vitoriosa a revolução de outubro de 1930, o governo provisorio da Republica pôs-se a estudar o assunto.

Tendo chamado a si, em toda a sua plenitude, as funções e atribuições, não só do poder executivo, como tambem

(11) Revista dos Tribunais, vol. 76, pag. 271. 
do poder legislativo, baixou o decr. n. 19.473, de 10 de dezembro de 1930, regulando os conhecimentos de transporte de mercadorias por terra, agua ou ar e dando outras providencias (12).

(12) Eis o seu texto, qual foi publicado no Diario Oficial, de 12 de dezembro de 1930:

DECRETO N. 19.473, DE 10 DE DEZEMBRO DE 1930.

Regula os conhecimentos de transporte de mercadorias por terra, agua ou ar, e dá outras providencias.

O Chefe do Governo Provisorio da Republica dos Estados Unidos do Brasil decreta:

Art. 1. - O conhecimento de frete original, emitido por emprezas de transporte por agua, terra ou ar, prova o recebimento da mercadoria e a obrigação de entrega-la no lugar do destino.

Reputa-se não escrita qualquer clausula restritiva, ou modificativa dessa prova, ou obrigação. texto.

E' titulo á ordem, salvo clausula ao portador, lançada no con-

Paragrafo unico. - Considera-se original o conhecimento do qual não constar a declaração de segunda, ou outra via.

Tais vias não podem circular, sendo emitidas somente para efeitos em face da empreza emissora.

Art. 2. - O conhecimento de frete deve conter:

I, o nome, ou denominação da empreza emissora;

II, o numero de ordem;

III, a data, com indicação de dia, mês e ano;

IV, os nomes do remetente e do consignatario, por extenso.

$O$ remetente pode designar-se como consignatario, e a indicação deste substituir-se pela clausula ao portador.

Será ao portador o conhecimento que não contiver a indicação do consignatario.

$\mathrm{V}$, o lugar da partida e o destino.

Faltando a indicação do lugar da partida, entende-se ser este o mesmo da emissão.

VI, a especie e a quantidade ou peso da mercadoria, bem como as marcas, os sinais exteriores dos volumes de embalagem;

VII, a importancia do frete e o lugar e a fórma do pagamento. 
Transformou-se o conhecimento de simples documento comprobatorio da recepção da mercadoria pela empreza de transportes e da sua obrigação de entrega-la no lugar do destino, em titulo representativo da propria mercadoria, dotado de poder circulatorio, por via do endosso, com a função especifica de transmitir a propriedade dela e de, em certas

A importancia será declarada por extenso e em algarismos, prevalecendo a primeira, em caso de divergencia.

Não indicada outra fórma, o pagamento será a dinheiro de contado e por inteiro, no ato da entrega da mercadoria e no lugar de destino, se outro não tiver sido designado.

A falta de pagamento de frete e despezas autoriza a retenção da mercadoria, á conta e risco de quem pertencer.

VIII, a assinatura do emprezario, ou seu representante, abaixo do contexto.

$\S 1$. - O conhecimento de frete maritimo conterá os requisitos determinados pelo art. 575 do codigo comercial.

$\S 2$. - O teôr do conhecimento póde ser, no todo ou em parte, manuscrito, datilografado, ou impresso; a assinatura do emprezario, ou seu representante, deve, porém, ser autentica.

$\S 3$. - O contexto incompleto, ou errado, póde ser completado, ou corrigido, mediante declaração da empreza emissora, lançada no anverso do titulo e devidamente datada e assinada pelo emprezario ou seu representante.

Art. 3. - O conhecimento nominativo é transferivel, sucessivamente, por endosso em preto, ou em branco, seguido da respetiva tradição.

E' em preto o endosso em que consta a indicação do nome, por extenso, do endossatario; em branco, aquele que o não contem.

$\S 1$. - O primeiro endossador deve ser o remetente, ou o consignatario.

§ 2. - O endosso em branco faz o titulo circular ao portador, até novo endosso. O portador póde preenche-lo.

$\S 3$. - O ultimo endossatario e detentor do conhecimento presume-se proprietario da mercadoria nele declarada (art. 2, n. VII).

A mera tradição manual transfere o conhecimento ao portador, ou endossado em branco, para o mesmo efeito.

Art. 4. - A clausula de mandato, inserta no teôr do endosso em preto, faz o endossatario procurador do endossador, com todos os poderes gerais e especiais relativos ao titulo; salvo restrição expres- 
condições, grava-la com o onus do penhor mercantil, como direito real de garantia.

Dando-lhe este feitio todo especial, emprestou-lhe requisitos capazes de lhe conferirem liquidês e certeza, sem embargo de lhe não dar a lei a força de escritura publica, como fez o codigo do comercio quanto ao conhecimento ma-

sa, constante do mesmo teôr. O substabelecimento do mandato pode dar-se mediante novo endosso, de igual especie.

Paragrafo unico. - Lançada a clausula de penhor ou garantia, o endossatario é credor pignoraticio do endossador.

Ele póde retirar a mercadoria, depositando-a, com a mesma clausula, em armazem geral, ou, senão, onde convier, de acôrdo com o endossador.

Póde tambem exigir, a todo o tempo, que o armazem geral emita o respetivo conhecimento de deposito e o warrant, ficando aquele á livre disposição do dono da mercadoria, e este á do credor pignoraticio para lhe ser entregue depois de devidamente endossado. A recusa do devedor pignoraticio de endossar o warrant sujeita-o á multa de dez por cento (10\%) sobre o valor da mercadoria, a beneficio do credor.

Sobre a mercadoria, depositada com clausula de penhor ou garantia, somente se expedirão esses titulos mediante assentimento do credor, que se não poderá opôr em se lhe oferecendo o respetivo warrant.

Art. 5. - O endosso deve ser puro e simples: reputam-se não escritas quaisquer clausulas condicionais ou modificalivas, não autorisadas por lei.

O endosso parcial é nulo.

O endosso cancelado considera-se anulado. Entretanto, é habil para justificar a serie das transmissões do titulo.

Art. 6. - O endossatario nominativo e o portador do conhecimento ficam investidos nos direitos e obrigações do consignatario, em face da empreza emissora.

$\mathrm{O}$ endossador responde pela legitimidade do conhecimento e existencia da mercadoria, para com os endossatarios posteriores, ou portadores.

Paragrafo unico. - E' sumaria a ação fundada no conhecimento de frete.

Art. 7. - O remetente, consignatario, endossatario ou portador póde, exibindo o conhecimento, exigir o desembarque e a entrega da 
ritimo. Não lhe diminuiu, todavia, a prestancia, nem lhe entorpeceu os movimentos, na circulação economica. Antes, bem livres os deixou.

Vindo ao encontro da pratica, trazida pelas circunstancias creadas pela retenção das safras nos armazens reguladores de distribuição dos cafés, atendeu a uma necessida-

mercadoria em transito, pagando o frete por inteiro e as despezas extraordinarias a que der causa. Extingue-se então o contrato de transporte e recolhe-se o respetivo conhecimento. dade.

o endossatario em penhor ou garantia não gosa dessa facul-

Art. 8. - A tradição do conhecimento ao consignatario, ao endossatario ou ao portador, exime a respetiva mercadoria de arresto, sequestro, penhora, arrecadação, ou qualquer outro embaraço judicial, por fato, divida, falencia, ou causa estranha ao proprio dono do titulo; salvo caso de má fé provada.

O conhecimento, porém, está sujeito a essas medidas judiciais, por causa que respeite ao respetivo dono atual. Neste caso a apteensão do conhecimento equivale á da mercadoria.

Art. 9. - Em caso de perda, ou extravio, do conhecimento, o remetente, consignatario, endossatario, ou portador, exibindo outra via ou certidão do titulo, fará, no fôro da comarca do lugar do destino, justificação do fato, com intimação do representante do Ministerio Publico, publicando-se, em seguida, editais na imprensa do lugar, em falta, na do mais proximo, e afixando-se como de costume, por cinco dias. Onde houver Bolsa de Mercadorias e Camara Sindical de Corretores, far-se-á publico pregão e aviso afixado a quem interessar possa.

Findo o prazo, aguardar-se-ão em cartorio mais quarenta e oito horas.

Se não aparecer oposição, o juiz proferirá sentença, nas subsequentes quarenta e oito horas, ordenando a expedição de mandado para entrega da mercadoria relativa ao conhecimento.

$\S$ 1. - Havendo oposição, o juiz marcará o prazo de cinco dias para a prova, arrazoando as partes afinal em dois dias cada uma. Conclusos os autos, a sentença deve ser proferida em cinco dias, ordenando ou denegando a entrega da mercadoria ao requerente ou ao opoente.

Todos os prazos independem de assinação em audiencia e correm em cartorio. 
de. Revestiu o conhecimento do transporte ferroviario da segurança, que the faltava.

Entrando a lei, desde logo, em execução, provocou larga serie de objeções, umas de ordem formal, e outras substantivas.

\section{AS OBSERVAÇŐES DA CONTADORIA CENTRAL} FERROVIARIA. - Pouco mais de um mês de execução tinha o decreto regulamentador dos conhecimentos de transporte e já, em 22 de janeiro de 1931, representava a Contadoria Central Ferroviaria ao ministro da Viação e Obras Publicas, sugerindo-lhe modificações em varios de seus ar. tigos.

Vale relembrar-lhe os termos:

"As estradas de ferro filiadas a esta Contadoria, em reunião realisada em 19 do corrente, trouxeram ao seio da Comissão de Tarifas a questão do conhecimento de transporte de mercadorias, materia a que o decr. n. 19.473, de 10 de dezembro de 1930, baixado pelo Governo Provisorio, vi-

§. - Da sentença, quer tenha havido ou não oposição, cabe agravo de petição.

Art. 10. - Os conhecimentos de despacho de bagagem, encomenda, animais, valores, transporte a domicilio, continuarão a reger-se pelo regulamento geral de transporte, que subsistirá em vigor, mesmo o concernente a mercadorias, em tudo quanto não colida com as disposições deste decreto e da lei n. 2.681, de 7 de dezembro de 1912.

Art. 11. - Este decreto entrará em vigor na data da sua publicação.

Paragrafo unico. - Os conhecimentos de frete de transportes terrestres já expedidos antes deste decreto segundo o estilo do lugar da emissão, consideram-se plenamente validos e gosam das regalias outorgadas neste mesmo decreto, embora haja ação, ou execução ainda pendente.

Art. 12. - Revogam-se as disposições em contrario.

Rio de Janeiro, 10 de dezembro de 1930, $109 .^{\circ}$ da Independencia, e 42..$^{\circ}$ da Republica. - GETULIO VARGAS. - José Maria Whitaker. 
sou dar novas disposições, atribuindo aos conhecimentos expedidos pelas estradas de ferro o valor de um documento negociavel.

As dificuldades de aplicação ás mercadorias em geral do decreto referido provocaram em todos os meios interessados iniciativas diversas em suas formulas, mas todas conducentes ao mesmo fim: harmonisar os objetivos do decreto com os principios em uso nas emprezas de transporte, resguardando uma serie de preceitos que sempre atenderam e ainda atendem simultaneamente ás necessidades do embarcador e do transportador, sem todavia prejudicar os intuitos em que se inspirou esse ato do governo: facilitar as negociações dos conhecimentos de café.

Do estudo procedido pela Comissão de Tarifas, resultou apurar-se que nem todos os dispositivos do decreto n. 19.473 satisfazem ás normas do serviço, observadas entre as estradas e os expedidores e, abandonando o que já existia de bom na materia, modificam certas disposições que acudiam de modo cabal ás exigencias dos embarques ferroviarios.

Não escapará a v. exa., sempre atento ao problema dos transportes, que a regulamentação dos serviços ferroviarios, no que respeita ao transporte, é feita de forma a conseguirse o objetivo de ser o mesmo realizado com segurança, exatidão e presteza.

Em consequencia do plano de valorisação do café, que teve por base a retenção prolongada dessa mercadoria nas estradas de ferro, desapareceu para esse transporte a condição de dever efetuar-se com presteza; por outro lado os conhecimentos correspondentes ficaram sujeitos ás mais variadas operações comerciais, e exigiram para a sua devida segurança certas alterações, como a de que foi objeto a portaria desse Ministerio, expedida em 11 de abril do ano p. passado, regulando a retirada das expedições de café.

Indispensaveis em relação ao café, as alterações consubstanciadas no decr. 19.473 não são aconselhaveis para as 
demais mercadorias, cujos conhecimentos em regra não estão sujeitos ás operações comerciais referidas e cujo transporte não poderia continuar a fazer-se com a devida presteza se aos mesmos tais alterações fossem aplicaveis. Sujeitos os transportadores ao arbitrio incontrastado dos interessados, cuja faculdade, conferida pelo art. 7 do decreto vai ao ponto de poder interromper o curso do transporte, é evidente que uma serie de embaraços deflue para as estradas de ferro, cujos serviços não devem ficar subordinados áquela condição, sem grave perigo para sua regularidade.

Entretanto, a questão já se encontra até certo ponto regulada com acerto nos atuais dispositivos do art. 65 do regulamento aprovado pela portaria de 25 de março de 1925, cujo texto diz:

"Art. 65. - Depois do carregamento do objeto despachado, far-se-á somente a modificação do despacho, a qual poderá ter logar em relação:

1, á estação de destino;

2 , ao consignatario.

§ 1. - Quando fôr alterada a estação de destino, a entrega far-se-á mediante apresentação do conhecimento e pagamento das despesas do transporte que as estradas precisarem efetuar para atender á alteração, além das previstas no art. $64, \S 1$.

$\S 2$. - As estradas não se obrigam a interromper a marcha de seus trens para diminuir o percurso relativo ao despacho modificado, bem como não alongarão inutilmente o referido percurso, depois de avisadas nos termos do regulamento.

§ 3. - A alteração de consignatario fica tambem sujeita ás taxas referidas no art. $64, \S 1$.

$\S 4$. - Nos casos do art. 63 , n. 2, as taxas anteriores serão pagas por quem pedir aos poderes competentes a anulação ou modificação, além das de armazenagem e outras peculiares ao caso." 
Bastaria, pois, para acorrer aos dispositivos do referido art. 7, substitui-los, como sugeriu a Comissão de Tarifas, observadas as necessarias adaptações quanto aos demais artigos e paragrafos nele compreendidos, pelo texto do art. 65 do regulamento geral dos transportes em vigor nas estradas filiadas a esta Contadoria, combinado com o que estatue o art. 80 do regulamento aprovado pelo decr. n. 10.202 , de 30 de abril de 1913, em vigor nas estradas paulistas, condensando-se toda a materia pela fórma abaixo:

“Art. 7. - Ao remetente será permitido, depois do carregamento do objeto despachado, modificar o despacho ou torna-lo sem efeito, se o conhecimento estiver em seu poder e a carga, embora despachada, ainda se encontrar na estação de procedencia.

§ 1. - 0 expedidor que quizer modificar o despacho, w: torna-lo sem efeito, e assim retirar a carga da estação, deverá restituir á estrada os documentos respetivos.

§ 2. - Quando a carga fôr retirada pelo remetente e o despacho ficar sem efeito, deverá o mesmo pagar as despesas de carregamento e descarga mencionadas na tarifa, alem das de armazenagem, se houver, recebendo da estação despachante a importancia do frete que tenha pago.

§ 3. - Quando fôr alterada a estação de destino, a entrega se fará mediante apresentação do conhecimento e pagamento das despezas do transporte decorrentes da alteração, cobrando-se a diferença de frete, ou restituindo-se o excesso se o frete fôr pago e estiver em divergencia com o novo despacho.

§ 4. - A estrada não se obriga a modificar o despacho de frete pago para frete a pagar, ou vice-versa, salvo se o engano provier do seu pessoal.

§ 5. - As estradas não se obrigam a interromper a marcha de seus trens para diminuir o percurso relativo ao despacho modificado, bem como não alongarão inutilmente o referido percurso, depois de avisadas nos termos de seus regulamentos". 
Outro ponto que á Comissão de Tarifas pareceu necessario modificar é o referente ao art. 9.

Prescrevendo esse artigo a fórma processual de substituição do conhecimento extraviado, isto é, sujeitando-se ás delongas e onus de um processo que suprime a retirada da mercadoria com recibo, agravam-se a cobrança de armazenagem, o atrazo da entrega, a falta de espaço nos armazens e a perda de mercadorias, quando estas forem de facil deterioração.

Esse processo não encontra justificativa, por subordinar a entrega de uma expedição, mesmo de valor insignificante, cujo conhecimento se tenha extraviado, a uma sentença de juiz, com todos os onus e delongas dos pleitos judiciarios. Aplicavel aos despachos de café, cujos conhecimentos, pelo elevado valor com que ordinariamente se caracterisam, menos sujeitos ficam a extravios, não se compreende a extensão que lhes consagra o art. 9, abrangendo em sua latitude mesmo os artigos de facil deterioração, cuja retirada não se compadece com o preenchimento das formalidades estabelecidas, sob pena de inutilisação da mercadoria.

Ora, o extravio de conhecimentos, por sua frequencia nos demais despachos, não comporta as providencias estabelecidas no citado art. 9, providencias que em muitos casos determinariam este absurdo: exceder a despesa do conhecimento o proprio valor da mercadoria.

Em concordancia com as entidades que estão se dedicando ao estudo e esclarecimento do decr. n. 19.473, a Contadoria Central Ferroviaria e Associação das Companhias de Estradas de Fierro do Brasil, a Comissão de Tarifas delegou a honra de sugerir a v. exa. a seguinte redação para o art. 9:

"Art. 9. - Em caso de perda, ou extravio, do conhecimento, a entrega só se fará por mandado judicial ou depois de publicada a perda ou extravio, pelo consignatario, durante cinco dias consecutivos, em editais, na imprensa do logar, em falta, no do mais proximo, sem reclamação ou protesto, mediante segunda via do conhecimento ou recibo. 
$\S 1$ - Para a retirada de mercadorias com recibo exigir-se-á que estes sejam assinados pelo consignatario ou por pessôa legalmente autorisada, só se efetuando a entrega depois de reconhecida sua idoneidade;

§ 2. - A pessôa, que retirar volumes com recibos, ficará responsavel por qualquer prejuizo se a mercadoria não lhe pertencer, embora a ela consignada, e é obrigada á restituição dos volumes se estiverem intactos ou a pagar seu justo valor ao verdadeiro dono".

Por outro lado, sendo o decreto inspirado no desejo de acudir á situação do café, e não havendo em relação a qualquer outra especie de mercadoria reclamação alguma, parece aconselhavel, seja do ponto de vista das garantias juridicas, seja pelo lado do serviço ferroviario, abolir-se uma transformação radical no sistema até ha pouco praticado. $\mathrm{E}$, nessas condições, a Comissão lembrou ainda que o art. 10 do decreto, limitando seus dispositivos ao transporte que se tem em vista regular, apenas disponha:

“Art. 10. - As determinações deste decreto só se aplicam aos conhecimentos de despachos de café, em quantidade superior a 10 sacas, subsistindo em vigor o regulamento geral dos transportes para os conhecimentos de bagagens, encomendas, animais, valores e outras mercadorias".

Concluindo, os representantes das estradas filiadas a esta Contadoria, reconheceram que, aceitas todas as modificações que tive a satisfação de apresentar a v. exa., não mais se explica a subsistencia do $\S$ unico do art. 11 do decr. $n$. 19.473, cujas disposições encerram uma aberração juridica, qual a de poderem ser as empresas condenadas, atualmente, por falta inexistente ao tempo em que se verificou o fato.

Assim é que o art. 11, § unico, do decreto, preceitúa:

"Os conhecimentos de fretes de transportes terrestres já expedidos antes deste decreto, segundo o estilo do logar da emissão, consideram-se plenamente validos e gosam das regalias outorgadas neste mesmo decreto, embora haja ação, ou execução, ainda pendente". 
A circunstancia de não se tratar de lei interpretativa, mas de um decreto que regula materia nova, repele o carater retroativo de que se reveste esta disposição, encerrando doutrina que fiere direitos patrimoniais preexistentes e fazendo retroagir seus efeitos a conhecimentos relativos a atos perfeitos e acabados, posto que ainda sub judice alguns deles.

No justo anseio de levar a v. exa., nos limites de sua responsabilidade e dentro do campo de suas atribuições, a colaboração que lhe cabe prestar por sua especialisação na materia, a Comissão de Tarifas, com o apoio da Associação Comercial do Rio de Janeiro, cujo representante se prontificou a secunda-la cooperando para o mesmo fim junto a outros departamentos da publica administração, deliberou que fossem submetidas á elevada apreciação de v. exa. as considerações que acabo de expôr, esperando que possam ser introduzidas no decreto as alterações sugeridas e removidas dentro em pouco as dificuldades apontadas"

\section{OS ESCLARECIMENTOS E SIMPLIFICAÇÕES} GOVERNAMENTAIS. - Encaminhadas ao governo essa longa e ponderada representação, firmada pelo inspetor $F_{E-}$ liciano de Souza Aguiar, e outras, novo decreto expediu ele, esclarecendo e simplificando o anterior e mercê do qual se lhe deu nova redação (13).

13. - Publicou o Diario Oficial, de 21 de março de 1931, os dois decretos seguintes:

\section{I}

DECRETO N. ${ }^{\circ}$ 19.754, DE 18 DE MARÇO DE 1931.

Esclarece e simplifica algumas disposições do decreto numero 19.473, de 10 de dezembro de 1930.

O Chefe do Governo Provisorio da Republica dos Estados Unidos do Brasil, atendendo á conveniencia de esclarecer e simplificar algumas disposições do decreto n. 19.473, de 10 de dezembro de 1930, decreta: 
Tres foram as modificações feitas: ao art. 2, n. VII, quanto a uma das enunciações do conhecimento; ao art. 9, substituindo o processo para a retirada da mercadoria em caso de perda ou extravio do conhecimento; ao art. 10, relativamente aos conhecimentos e entrega de bagagens e outros despachos, que continuaram a reger-se pelo regulamento geral dos transportes.

Art. 1. - $\mathrm{O}$ n. VII do artigo 2 do referido decreto fica assim redigido:

"VII - A importancia do frete com a declaração de que é pago ou a pagar, e do lugar e da forma do pagamento.

A importancia será declarada por extenso e em algarismos, prevalecendo a primeira em caso de divergencia.

Emitido o conhecimento com frete a pagar e não indicada a fórma do pagamento, este será a dinheiro de contado e por inteiro, se outro não tiver sido designado. A falta de pagamento do frete e despezas autoriza a retenção da mercadoria.

0 art. $90^{\circ}$ do mesmo decreto fica assim redigido:

Art. 9. ${ }^{\circ}$ Em caso de perda, ou extravio, do conhecimento, qualquer interessado póde avisar a empreza do transporte, no lugar do destino, para que retenha a respetiva mercadoria.

$\S 10^{\circ}$ - Se o aviso provier do consignatario, ou do remetente, a empreza anunciará o fato tres vezes consecutivas, á custa do comunicante, pela imprensa do lugar do destino, se houver, senão pela da Capital do Estado, ou da localidade mais proxima que a tenha.

Não havendo reclamação relativa á propriedade, ou penhor, do conhecimento durante os dias do anuncio e mais os dous imediatos, a mercadoria será entregue ao notificante de acôrdo com as disposições legais ou regulamentares.

Se o aviso provier de outrem que não o consignatario ou o remetente, valerá como reclamação contra a entrega da mercadoria, para ser judicialmente processada na fórma do $\S 2 .^{\circ}$ a seguir.

$\S 2 .^{\circ}$ Havendo reclamação, a mercadoria não será entregue e o reclamante, exibindo outra via ou certidão do conhecimento, fará, no fôro da comarca do lugar do destino, justificação do fato e do seu direito, com intimação do orgão do Ministerio Publico, publicando-se, em seguida, editais como determina o $\S 10^{\circ}$ deste artigo, e afixando-se como de costume. Onde houver Bolsa de Mercadorias e Camara Sindical de Corretores, far-se-á publico prégão e aviso a quem interessar possa.

Findo o prazo, aguarda-se-āo mais quarenta e oito horas.

Se não aparecer oposição, o juiz proferirá sentença, nas subse- 
Ouviu o governo as criticas e observações, com animo de transigir e de acertar. Os reparos eram procedentes, especialmente os referentes a certas dificuldades que iam verificar-se diante da rigidês do decreto acerca da representação das mercadorias despachadas pelo respetivo conhe-

quentes, quarenta e oito horas e, uma vês passado o prazo para o agravo $\left(\S 5 .^{\circ}\right)$, poderá ordenar a expedição de mandado de entrega da mercadoria ao reclamante.

$\S 3 .^{\circ}$ Havendo oposição, o juiz marcará o prazo de cinco dias para prova, arrazoando as partes afinal, no prazo de dous dias cada uma. Conclusos os autos, o juiz proferirá sentença em cinco dias.

$\S 4 .^{\circ}$ Todos os prazos judiciais correrão em cartorio, independentemente de assinação em audiencia.

$\S 5 .^{\circ}$ Da sentença, tenha, ou não, havido oposição, caberá agravo de petição.

$\S 60^{\circ}$ A exibição de conhecimento original suspenderá as diligencias judiciais e extra-judiciais prescritas pelo presente arligo, continuando o titulo a produzir plenamente os efeitos que lhe são proprios.

$\S 7 .^{\circ}$ As mercadorias de valor até um conto de réis poderão ser retiradas, independentemente do conhecimento, mediante as cautelas instituidas nas leis ou regulamentos em vigôr. A estimativa desse valor, não tendo sido feita na ocasião do despacho, competirá ao prudente arbitrio da empreza de transporte, no momento da entrega da mercadoria.

$\S 8 .^{\circ}-$ A empreza poderá requerer o deposito por conta de quem pertencer a mercadoria não retirada em tempo, nos casos permitidos em lei ou regulamento, bem como no do $\S 2 .^{\circ}$ deste artigo.

Continuam em vigor as disposições relativas aos generos perigosos, nocivos ou de facil deterioração. Os generos alimenticios, destinados a consumo imediato, poderão ser entregues ao destinatario, em falta de conhecimento, mediante as formalidades usuais.

$\mathrm{O}$ art. $10 .^{\circ}$ do mesmo decreto fica assim redigido:

Art. 10. Os conhecimentos e a entrega de bagagem, encomenda, bem como de animais, valores e objetos remetidos a domicilio continuarão a reger-se pelo regulamento geral dos transportes, o qual continuará em vigor, mesmo no concernente a cargas, em tudo quanto não colida com as disposições deste decreto e da lei n. 2.681, de 7 de dezembro de 1912.

Art. 2..$^{\circ}$ Far-se-á nova publicação do decreto numero 19.473 , de 10 de dezembro de 1930 , com as alterações constantes deste. 
cimento. Adquirira este novo aspeto. Dotado de certos requisitos, passava a funcionar como titulo autonomo, formal, circulando como se fossem as proprias mercadorias nele descritas e por ele representadas.

Num titulo de credito se converteu, desde que tal se entenda o necessario para fazer valer o direito nele literal-

Art. 3. ${ }^{\circ}$ Revogam-se as disposições em contrario.

Rio de Janeiro, 18 de março de $1931,1100^{\circ}$ da Independencia e 43. ${ }^{\circ}$ da Republica. - GETULIO VARGAS. - José Maria Whitaker.

\section{II}

DECRETO N. 19.473 - DE 10 DE DEZEMBRO DE 1930, COM MODIFICAÇÕES FEITAS PELO DECRETO N.` 19.754, DE 18 DE MARÇO DE 1931

Regula os conhecimentos de transporte de mercadorias por terra, agua ou ar, e dá outras providencias.

O Chefe do Governo Provisorio da Republica dos Estados Unidos do Brasil, decreta:

Art. $10^{\circ}$ O conhecimento de frete original, emitido por emprezas de transporte por agua, terra ou ar, prova o recebimento da mercadoria e a obrigação de entrega-la no lugar do destino.

Reputa-se não escrita qualquer clausula restritiva, ou modificativa, dessa prova, ou obrigação.

E' titulo á ordem, salvo clausula ao portador, lançada no contexto.

Paragrafo unico. Considera-se original o conhecimento do qual. não constar a declaração de segunda, ou outra via.

Tais vias não podem circular, sendo emitidas sómente para efeitos em face da empreza emissora.

Art. $2 .^{\circ}$ O conhecimento de frete deve conter:

I - O nome, ou denominação da empreza emissora;

II - $O$ numero de ordem;

III - A data, com indicação de dia, mês e ano;

IV - Os nomes do remetente e do consignatario, por extenso.

O remetente póde designar-se como consignatario, e a indicação deste substituir-se pela clausula ao portador.

Será ao portador o conhecimento que não contiver a indicação do consignatario;

$\mathrm{V}$ - O lugar da partida e do destino. 
mente exarado, e exatamente por ser representativo das mercadorias despachadas por via dele.

No capitulo dos titulos de credito do projeto de codigo comercial italiano, conceituou Cesare Vivante como representativos de mercadorias os que atribum ao seu legitimo possuidor o exclusivo direito ao recebimento das nele determi-

Faltando a indicação do lugar da partida, entende-se ser este o mesmo da emissão;

VI - A especie e a quantidade ou peso da mercadoria bem como as marcas, os sinais exteriores dos volumes de embalagem;

VII - A importancia do frete, com a declaração de que foi pago ou a pagar, e do lugar e da fórma do pagamento.

A importancia será declarada por extenso e em algarismos, prevalecendo a primeira em caso de divergencia.

Emitido o conhecimento com frete a pagar e não indicada a forma do pagamento, este será a dinheiro de contado e por inteiro, no ato da entrega da mercadoria e no lugar do destino, se outro não tiver sido designado. A falta de pagamento do frete e despesas autoriza a retenção da mercadoria;

VIII - A assignatura do emprezario, ou seu representante, abaixo do contexto.

$\S 1 .^{\circ} \mathrm{O}$ conbecimento de frete maritimo conterá os requisitos determinados pelo art. 575 do Codigo Comercial.

$\S 2 .^{\circ} \quad$ O teôr do conhecimento póde ser, no todo ou em parte, manuscrito, datilografado ou impresso; a assinatura do emprezario, ou seu representante, deve, porém, ser autentica.

$\S 3 .^{\circ}$ O contexto incompleto, ou errado, póde ser completado, ou corrigido, mediante declaração escrita da empreza emissora, lançada no anverso do titulo e devidamente datada e assinada pelo emprezario ou seu representante.

Art. $3 .^{\circ} \mathrm{O}$ conhecimento nominativo é transferivel, sucessivamente, por endosso em preto, ou em branco, seguido da respetiva tradição.

E' em preto o endosso em que consta a indicação do nome, por extenso, do endossatario; em branco, aquele que o não contém.

$\S 10^{\circ}$ o primeiro endossador deve ser o remetente, ou o consignatario.

$\S 2 .^{\circ} \quad$ O endosso em branco faz o titulo circular ao portador, até novo endosso. $O$ portador póde preenche-lo.

$\S 3 .^{\circ}$ O ultimo endossatario e detentor do conhecimento presư me-se proprietario da mercadoria nele declarada (artigo $2 .^{\circ}, \mathrm{n}$. VII) 
nadas. E esse mesmo principio apareceu no projeto MARIANo D'amelio em outros termos desenvolvido. Os titulos representativos de mercadorias atribuem, ficou expresso no art. 423, ao seu legitimo possuidor o exclusivo direito de dispôr das mercadorias nele mencionadas. E acentuou, em alinea, regular-se a circulação das mercadorias representadas

A méra tradição manual transfere o conhecimento ao portador, ou endossado em branco, para o mesmo efeito.

Art. $4 .^{\circ}$ A clausula de mandato, inserta no teôr do endosso em preto faz o endossatario procurador do endossador, com todos os poderes gerais e especiais relativos ao titulo; salvo restrição expressa, constante do mesmo teôr. O substabelecimento do mandato póde dar-se mediante novo endasso, de igual especie.

Paragrafo unico. Lançada a clausula de penhor ou garantia, o endossatario é credor pignoraticio do endossador.

Ele póde retirar a mercadoria, depositando-a, con a mesma clausula, em armazem-geral, ou, senão, onde convier, de acôrdo com o endossador.

Póde tambem exigir, a todo tempo, que o armazem-geral emita o respetivo conhecimento de deposito e o warrant, ficando aquele á livre disposição do dono da mercadoria, e este á do credor pignoraticio para lhe ser entregue depois de devidamente endossado. A recusa do devedor pignoraticio de endossar o warrant sujeita-o á multa de dez por cento $(\mathbf{1 0 \%})$ sobre o valor da mercadoria, a beneficio do credor.

Sobre a mercadoria, depositada com clausula de penhor ou garantia, sómente se expedirão esses titulos mediante assentimento do credor que se não poderá opôr em se lhe oferecendo o respetivo warrant.

Art. 5. $\mathrm{O}$ endosso deve ser puro e simples: reputam-se não escritas quaisquer clausulas condicionais ou modificativas, não autorizadas em lei.

O endasso parcial é nulo.

O endosso cancelado considera-se anulado. Entretanto, é habil para justificar a série das transmissões do titulo.

Art. $6 .^{\circ} \mathrm{O}$ endossatario nominativo e o portador do conhecimento ficam investidos nos direitos e obrigações do consignatario, em face da empreza emissora.

O endossador responde pela legitimidade do conhecimento e existencia da mercadoria, para com os endossatarios posteriores, ou portadores. 
pelo titulo de credito pela lei reguladora da disciplina do mesmo titulo, a tal ponto, prosseguiu no art. 524, que o se-

\footnotetext{
Paragrafo unico. E' sumaria a ação fundada no conhecimento de fréte.

Art. 7. O remetente, consignatario, endossatario ou portador póde, exibindo o conhecimento, exigir o desembarque e a entrega da mercadoria em transito, pagando o fréte por inteiro e as despezas extraordinarias a que dér causa. Extingue-se então, o contrato de transporte e recolhe-se o respetivo conhecimento.

$O$ endossatario em penhor ou garantia não goza dessa faculdade.
}

Art. $8 .^{\circ}$ - A tradição do conhecimento ao consignatario, ao endossatario ou ao portador, exime a respetiva mercadoria de arresto, sequestro, penhora, arrecadação, ou qualquer outro embaraço judicial, por fato, divida, falencia, ou causa extranha ao proprio dono atual do titulo; salvo caso de má fé provada.

O conhecimento, porém, está sujeito a essas medidas judiciais, por causa que respeite ao respetivo dono atual. Neste caso, a apreensão do conhecimento equivale á da mercadoria.

Art. 9. ${ }^{\circ}$ Em caso de perda, ou extravio, do conhecimento, qualquer interessado póde avisar a empreza de transporte, no lugar do destino, para que retenha a respetiva mercadoria.

$\S 1 .^{\circ}$ Se o aviso provier do consignatario, ou do remetente, a empreza anunciará o fato tres vezes consecutivas, á custa do comunicante, pela imprensa do Iugar do destino, se houver, senão pela da Capital do Estado, ou da localidade mais proxima que a tenha.

Não havendo reclamação relativa á propriedade, ou penhor, do conhecimento durante os dias do anuncio e mais os dous imediatos, a mercadoria será entregue ao notificante de acôrdo com as disposições legais ou regulamentares.

Se o aviso proviér de outrem, que não o consignatario, ou o remetente, valerá como reclamação contra a entrega da mercadoria, para ser judicialmente processada na fórma do $\S 2 .^{\circ}$, a seguir.

$\S 2 .^{\circ}$ Havendo reclamação, a mercadoria não será entregue e o reclamante, exibindo outra via ou certidão do conhecimento, fará, no fôro da comarca do lugar do destino, justificação do fato e do seu direito, com intimação do orgão do Ministerio Publico, publicando-se, em seguida, editais como determina o $\S 1 .^{\circ}$, deste artigo, e afixando-se como de costume. Onde houver Bolsa de Mercadorias e Camara Sindical de Corretores, far-se-á publico prégão e aviso a quem interessar possa.

Findo o prazo, aguardar-se-ão mais quarenta e oito horas. 
questro, a penhora e qualquer outro vinculo sobre direito no titulo mencionado, ou sobre as mercadorias por ele re-

Se não aparecer oposição, o juiz proferirá sentença, nas subsequentes quarenta e oito horas e, uma vês passado o prazo para o agravo $\left(\S 5 .^{\circ}\right)$, poderá ordenar a expedição de mandado de entrega da mercadoria ao reclamante.

$\S 3 .^{\circ}$ Havendo oposição, o juiz marcará o prazo de cinco dias para prova, arrazoando as partes, afinal, no prazo de dous dias cada uma. Conclusos os autos, o juiz proferirá sentença em cinco dias.

$\S 4 .^{\circ}$ Todos os prazos judiciais correrão em cartorio, independentemente de assinação em audiencia.

$\S 5 .^{\circ}$ Da sentença, tenha, ou não, havido oposição, caberá agravo de petição.

$\S 60^{\circ}$ A exibição do conhecimento original suspenderá as diligencias judiciais e extrajudiciais prescritas pelo presente artigo, continuando o titulo a produzir plenamente os efeitos que lhe são proprios.

$\S 7 .^{\circ}$ As mercadorias de valor até um conto de réis, poderão ser retiradas, independentemente do conhecimento, mediante as cautelas instituidas nas leis ou regulamentos em vigor. A estimativa desse valor, não tendo sido feita na ocasião do despacho, competirá ao prudente arbitrio da empreza do transporte no momento da entrega da mercadoría.

$\S 8 .^{\circ}$ A empreza poderá requerer o deposito por conta de quem pertencer a mercadoria não retirada em tempo, nós casos permitidos em lei ou regulamento, bem como no do $\S 2 .^{\circ}$ deste artigo.

Continuam em vigor as disposições relativas aos generos perigosos, nocivos ou de facil deterioração. Os generos alimenticios, destinados a consumo imediato, poderão ser entregues ao destinatario, em falta de conhecimento, mediante as formalidades usuais.

Art. 10. Os conhecimentos e a entrega de bagagem, encomenda, bem como de animais, valores e objetos remetidos a domicilio, continuarão a reger-se pelo regulamento geral dos transportes, o qual continuará em vigor, mesmo no concernente a cargas, em tudo quanto não colida com as disposições deste decreto e da lei n. 2.681, de 7 de dezembro de 1912.

Art. 11. Este decreto entrará em vigor na data da sua publicação.

Paragrafo unico. Os conhecimentos de fréte de transportes terrestres já expedidos antes deste decreto, segundo o estilo do lugar da emissão, consideram-se plenamente válidos e gozam das regalias 
presentadas, não é eficaz senão quando atinge o proprio titulo (14).

Eis o espirito de que se imbuiu o decreto regulamentador do conhecimento de transporte por terra, agua ou ar.

Por isso mesmo, e sem embargo das reformas, que lhe foram introduzidas, algumas dificuldades subsistiram.

Era de mister quebrar ainda certas arestas, que terião desaparecido com a permissão de expedirem as emprezas de transporte, á vontade do comitente, ou o conhecimento ou um simples recibo da carga, com as formalidades daquele, mas sem os seus efeitos juridicos.

Creou o governo, então, por outro decreto, o de n. 20.454, de 29 de setembro de 1931, o conhecimento não á ordem. Estabeleceu, ao mesmo passo, regras para o recebimento da carga, no caso de seu extravio ou perda (15).

outorgadas neste mesmo decreto, embora haja ação, ou execução ainda pendente.

Art. 12. Revogam-se as disposições em contrario.

Rio de Janeiro. 10 de dezembro de $1930109 .^{\circ}$ da Independencia, e $42 .^{\circ}$ da Republica. - GETULIO VARGAS. - José Maria Whitaker.

(14) Progetto preliminare per il nuovo Ciodice di Commercio. Ed. Hoepli. Milão, 1922, Pag. 104. — Codice di Comercio. Progetto. Roma, 1927, Vol. 1, pag. 169.

(15) Eis o seu texto, publicado no Diario Oficial, de 2 de outubro de 1931:

DECRETO N. ${ }^{\circ} 20.454$ - DE 29 DE SETEMBRO DE 1931

Regula os conhecimentos de frete emitidos não á ordem e dá outras providencias.

O Chefe do Govêrno Provisorio da Republica dos Estados Unidos do Brasil, usando das atribuições contidas no art. $1 .^{\circ}$ do decreto n. 19.398 , de 11 de novembro de 1930, decreta:

Art. $10^{\circ}$ O conhecimento de frete nominativo póde ser emitido não á ordem, mediante clausula expressa inserida no contexto.

Art. $2 .^{\circ}$ Em caso de perda, destruição, furto, ou roubo, de conhecimento de frete não á ordem, a entrega da respetiva mercadoria 
15. O CONHECIMENTO DE FRETE E OS SEUS RFQUISITOS. - Tanto que receba em seus armazens, depositos, estações, agencias ou pontos de embarques a mercadoria, de cujo transporte vai incumbir-se, expedirá a empreza o respetivo conhecimento de frete, em original, se numa unica via, ou em tantas quantas o regulamento determine e o remetente exija, sendo, neste caso, todas as vias numeradas, em ordem ascendente.

Póde exarar-se o seu teôr, no todo ou em parte, por manuscrito, datilografia ou impressão. Usam-se, em regra, fórmulas impressas em parte, contendo claros que se preencherão manuscritamente no momento do despacho com as enunciações relativas a cada expedição.

Enumerou a lei os requisitos do conhecimento.

E são estes:

\section{I, o nome, ou denominação da empreza emissora.}

O nome é, no caso, a locução por via da qual a empreza de transportes se individualiza no mundo industrial ou mercantil. Póde, por isso mesmo, confundir-se com a denominação e, até, dar-se a sua coexistencia.

se fará ao destinatario por segunda via, ou certificado do despacho, de acôrdo com os regulamentos em vigor.

Se, entretanto, a empreza de transportes tiver aviso de cessão, ou penhor, do conhecimento, depositará a mercadoria por conta e risco de quem pertencer.

Art. $3 .^{\circ}$ O presente decreto entrará em vigor dêsde a data da sua publicação oficial.

Art. $4 .^{\circ}$ Revogam-se as disposições em contrario.

Rio de Janeiro, 29 de setembro de $1931,1100^{\circ}$ da Independencia e $43 .^{\circ}$ da Republica. - GETULIO VARGAS. - José Maria Whitaker. 
Na ordem civil, o nome designa a pessoa natural: individualiza o cidadão. E' o que o registro do seu nascimento lhe atribue: compõe-se do nome, propriamente dito, e do pre. nome. Este é imutavel e aquele mutavel somente por exceção e mercê de despacho judicial (decr. n. 18.542, de 24 de dezembro de 1928, arts. 68 a 70 ).

$\mathrm{Na}$ orbita comercial, o nome designa o comerciante, pessôa natural ou juridica. Se natural, o seu proprio nome civil, por extenso ou abreviadamente, com aditamento de designação mais precisa de sua pessôa ou genero de negocio - a sua firma individual, nome com o qual exercerá o seu comercio e assinará os atos e contratos a ele referentes (decr. n. 916, de 24 de outubro de 1890, arts. 2 e 3); se juridica, o nome civil de um ou de cada um de seus socios de responsabilidade solidaria, por extenso ou abreviadamente, com a clausula " $\mathrm{e}$ companhia", sob a qual se incluirão os de responsabilidade limitada e os que não figurarem na sua expressão: a sua firma ou razão social, organisada nos estritos termos da lei creadora do seu registro. Revestindo, entretanto, a sociedadade a fórma anonima terá, em vez de firma ou razão social, uma denominação particular, indicativa, se possivel, de seu objeto (decr. n. 916, art. 4; decr. n. 434, de 4 de julho de 1891, art. 14), que tambem poderá ser adotada pela sociedade comanditaria por ações (decr. n. 434, art. 218) ; pela por quotas, de responsabilidade limitada (decr. n. 3.708, de 10 de janeiro de 1919, art. 3) e pela cooperativa (decr. n. 1.637, de 5 de janeiro de 1907, art. 12).

Nem só a pessoa juridica poderá ter denominação, cabivel ao seu proprio estabelecimento, quasi sempre por ela conhecido. Muitas vêses a denominação da sociedade é a mesmo do seu estabelecimento. Mas podem ser diferentes.

Em qualquer das hipoteses, a denominação, seja da pessôa juridica, seja do estabelecimento, é genero da especie nome comercial, que compreende:

a) a firma individual do comerciante; 
b) a firma ou razão social ou a denominação da sociedade mercantil;

c) a denominação da loja, casa, estabelecimento, empreza, fabrica ou usina.

Incluem outros, tambem, a designação da localidade de procedencia da mercadoria ou do produto natural ou industrial.

Se, pois, a empreza de transportes pertencer a um comerciante com firma individual ou social e tiver uma denominação, no conhecimento se indicará a firma, ou a denominação, senão as duas:

\section{EMPREZA BRASILEIRA DE TRANSPORTES Alencar, Lima \& Cia.}

Não tendo denominação, consignar-se-á simplesmente a firma.

Ou a denominação social:

\section{COMPANHIA PAULISTA DE ESTRADAS DE FERRO,} que porá em evidencia não apenas a personalidade juridica da sociedade, senão a sua empreza de transportes.

\section{II, o numero de ordem.}

Para segurança do serviço são as formulas do conhecimento, em regra, encadernadas em volume, contendo cada uma o seu talão ou toco, de que se separa por uma linha picotada, afim de ser destacada, com as mesmas partes impressas e os mesmos espaços em branco. Outras vêses, em lugar do talão, varias folhas subpostas, impressas em parte, com os mesmos claros da primeira, afim de, por via de papel carbono, tirarem-se quantias vias necessarias fôrem.

Cada formula terá o seu numero, seguindo-se-lhe as outras numeradas em ordem ascendente, ou já impresso, ou manuscrito no ato ou aposto por meio de carimbo. 
A numeração, em ordem seguida, alem da garantia do serviço, facilitando-lhe o controlo, e da facilidade da busca, em caso de reclamação ou perda, tanto do conhecimento, quanto da mercadoria, terá a vantagem de fornecer elemento para uma organisação de estatisticas.

$$
\begin{aligned}
& \text { III, a data, com indicação de dia, mês } \\
& e \text { ano. }
\end{aligned}
$$

Importando a emissão do conhecimento na obrigação da entrega da carga despachada, mister é fixar o momento de seu inicio. Obtem-se isso pela data, indicando o dia, o mês e ano do recebimento da mercadoria. A responsabilidade do condutor ou comissario de transportes, diz o art. 101 do código do comercio, começa a correr desde o momento em que recebe as fazendas, e só expira depois de efetuada a entrega. Esclarecendo esse principio, o art. 3 do decr. $n$. 2.681, de 7 de dezembro de 1912, assentou começar essa responsabilidade "ao ser recebida a mercadoria na estação pelos empregados da estrada de ferro, antes mesmo do despacho e terminará ao ser efetivamente entregue ao destinatario".

Poderá a formula ter impressos os dizeres necessarios, deixando abertos os topicos a serem preenchidos, ou por carimbo, ou por manuscrito.

IV, os nomes do remetente e do consignatario, por extenso.

Contrato bilateral, por via do qual a empreza recebe mercadorias afim de conduzi-las, mediante o pagamento de certo preço: o frete, para determinado lugar e entrega-las á pessôa a que vão destinadas, o de transporte, revelando-se pelo conhecimento, mencionará, por extenso, os nomes do remetente e do consignatario.

Chama-se ao remetente, tambem, de carregador, de consignante: é o que, por conta propria ou alheia, expede e 
envia a mercadoria. Quando ele fizer o despacho por sua propria conta, poderá designar-se como consignatario. Escrever-se-á, nesse caso, o seu nome por extenso, ou clausula que o substitua sem deixar duvida:

Remetente: Joaquim dos Santos.

Consignatario: o mesmo, ou: o remetente.

Duvidas têm surgido quando negociantes, tendo abreviado o seu nome em sua firma comercial, C. Nogueira, por exemplo, por ela se designam como destinatarios ou remetentes. Exigindo a lei os nomes por extenso, resolveram algumas estradas de ferro, em tais casos, após á firma, consignar a declaração de tratar-se de firma comercial.

Licito lhe será substituir a designação do consignatario pela clausula ao portador:

Consignatario: o portador.

Facilita-se, com a indicação dos nomes do remetente e do consignatario, por extenso, a execução do contrato pela empreza. Se a lei a exime do direito de verificar se o remetente é o proprietario ou possuidor da mercadoria, ou o titulo por que será entregue ao destinatario, lhe impõe a obrigação de fazer-lhe a entrega. A ele ou a quem o remetente determinar, senão ao portador.

Com estes é que o transportador terá de entender-se.

Nenhuma duvida deverá pairar, portanto, quanto ás suas identidades.

A omissão do nome do destinatario não invalidará o conhecimento.

Será ao portador.

V, o lugar da partida e do destino.

Não somente no tempo se inicia a obrigação, mas tambem no espaço. Convem saber onde recebeu a empreza a mercadoria por motivos de varia natureza e fins.

Correm, confórme dispõe o art. 103 do codigo do comercio, as perdas ou avarias acontecidas ás fazendas, durante o transporte, não provindo de vicio, força maior ou ca- 
so fortuito, por conta do condutor ou comissario de transportes.

Determinar-se-á, portanto, o lugar onde começaram os riscos a correr por conta do transportador.

Faltando, entretanto, a indicação do lugar da partida, entende-se ser este o mesmo da emissão do conhecimento.

O lugar do destino deve sempre ser designado. Tem as mais variadas consequencias. Por ele se estabelecerá o preço do frete nas ferrovias, calculado pelo numero de quilometros entre o lugar do embarque e o do destino. Fixa o lugar onde o destinatario deverá procurar e receber a carga, afim de libertar-se das despezas de armazenagem pelo tempo da demora no recebimento.

VI, a especie e a quantidade ou peso das mercadorias, bem como as marcas, os sinais exteriores dos volumes de embalagem

Descrever-se-á a mercadoria pela sua especie ou qualidade, afim de se não receber diversa da despachada: uma partida de milho por uma de café. Evitar-se-ão trocas, muitas vêses fraudulentas. Distinguem-se as mercadorias pela sua substancia, pelo seu nome, pelos seus tipos, pela sua procedencia.

A quantidade expressar-se-á por numeros: unidade, duzias, grosas; por medida linear, tendo por base o metro, seus multiplos e submultiplos; pela medida de capacidade, por litros, suas subdivisões e seus multiplos.

$\mathrm{Ou}$, então, pelo seu peso, tendo por base o quilograma, as suas subdivisões e os seus multiplos, seja o peso bruto, comprehendendo o da mercadoria e o da sua embalagem ou continente; seja o peso liquido, exclusivamente da mercadoria.

A diferença entre o peso liquido e o bruto é a tara, fixada por um calculo medio sobre o peso bruto quando se- 
ja dificil ou impossivel o desenfardamento ou o desencaixotamento.

Variam as tarifas de transporte com as qualidades e a quantidade das mercadorias. Anexo ao regulamento de transportes aprovou o governo a tabela de sua classificação, artigo por artigo.

Tornou o art. 5 do decr. n. 2.681, de 7 de dezembro de 1912, regulador da responsabilidade civil das estradas de ferro, por tudo isso, "obrigatoria, por parte do remetente, a declaração da natureza e valor das mercadorias que forem entregues fechadas".

E a expressão "natureza", como é sabido, compreende o genero e as especies das cousas.

Não somente pela especie, quantidade ou peso se identificará a mercadoria despachada. Mas tambem pelas marcas ou sinais exteriores dos volumes de embalagem.

$\mathrm{Ha}$, todavia, marcas e marcas: as letras ou iniciais do nome do remetente, revestidas, ou não, de desenhos ou ceŕcaduras especiais :

variando de comerciante para comerciante, ou de artigo para arti-

A. C. go, estampadas ou carimbadas, ou fazendo parte do tecido, quando a

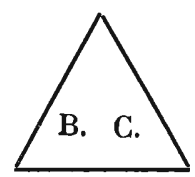
embalagem seja por sacaria ou enfardamento; ou as marcas de industria e de comercio, registradas na conformidade do decr. n. 16.264, de 19 de dezembro de 1923.

Mencionar-se-ão, portanto, todos os sinais exteriores dos volumes de embalagem, afim de evitar duvidas quanto à identidade da mercadoria a entregar.

VII, a importancia do frete, com a declaração de que é pago ou a pagar, $e$ do lugar e da fórma do pagxmento.

Seja o despacho feito com frete pago no ato da expedição ou a pagar no de efetiva entrega na estação ou lugar 
do destino, a sua importancia será mencionada por extenso e em algarismos.

Em caso de divergencia entre as duas declarações, prevalecerá a escrita por extenso.

Emitido o conhecimento com frete a pagar e não indicada a fórma do pagamento, este será a dinheiro de contado e por inteiro, no ato da entrega da mercadoria e no lugar do destino, se outro não tiver sido designado.

A falta de pagamento do frete e das despezas autoriza a retenção, pela empreza ferroviaria, da mercadoria.

VIII, a assinatura do emprezario ou seu representante, abaixo do contexto.

Expedido o conhecimento e assumindo as obrigações dele decorrentes, deve o emprezario ou o seu representante assina-lo. Essa assinatura, adverte o texto legal, deve ser autentica.

Como representantes das emprezas ferroviarias se entendem não somente os seus diretores, orgãos representativos da personalidade juridica, como os seus prepostos, sejam agentes de estação, despachantes, sejam outros, com o mesmo mister, mas com diversa classificação.

Representam os prepostos aos preponentes. Porque os representam e ajem em nome e por conta deles, o codigo de comercio, no art. 75, preceituou serem eles responsaveis pelos atos dos seus feitores, guarda livros, caixeiros e outros quaisquer prepostos, praticados dentro das suas casas de comercio, que forem relativos ao seu giro comercial, ainda que se não achem autorizados por escrito.

Quem, efetivamente, conduz a sua mercadoria á estação ou agencia da estrada de ferro e a entrega ao empregado incumbido de realizar o despacho, não é obrigado a solicitar-lhe a exibição de sua procuração ou de documento concedendo-lhe poderes para receber a carga e assinar o respetivo conhecimento. 
Por isso, e para evitar os atritos que poderiam surgir nessa verificação de poderes, refere o codigo, no art. 76, sempre que algum comerciante encarregar um feitor, caixeiro ou outro qualquer preposto do recebimento de fazendas compradas, ou que por qualquer outro titulo devam entrar em seu poder, e o feitor, caixeiro ou preposto as receber sem objeção ou protesto, a entrega será tida por bôa, sem ser admitida ao preponente reclamação alguma.

Para o caso, de resto, expressamente dispôs o art. 3 do dec. n. 2.684, de 7 de dezembro de 1912, que "a responsabilidade começará, ao ser recebida a mercadoria na estação pelos empregados da estrada de ferro, antes mesmo do despacho, e terminará ao ser efetivamente entregue ao destinatario".

O contexto incompleto, ou errado, do conhecimento poderá ser completado, ou corrigido, mediante declaração escrita da empreza emissora, lançada no anverso do titulo e devidamente datada e assinada pelo emprezario ou seu representante.

16. A FUNÇÃO DO CONHECIMENTO. - Com todos esses requisitos, o conhecimento:

a) prova o recebimento da mercadoria e a obrigação de entrega-la no lugar do destino;

b) representa a mercadoria e, como titulo de credito, circula e facilita-lhe a transmissão.

No seu primeiro aspecto, funciona como meio de prova, tanto do recebimento, quanto da obrigação de restituir $e$ a lei reputa não escrita qualquer clausula modificativa ou restritiva dessa prova e desta obrigação. Não se compreende a emissão do conhecimento de favor, sem o recebimento pelo transportador da cousa nele indicada. Tem, realmente, aparecido casos de emissão fraudulenta de conhecimentos desse naipe. A fraude é onimoda e astuciosa. Isso, entretanto, é muito raro. Mais comum tem sido a adulteração do conhecimento pela indicação de maior numero 
de cousas do que as efetivamente transportadas, pelo acrescimo de um ou mais algarismos.

A lei, porém, é categorica. Nem podia ser de outra fórma. Convertido em titulo circulatorio, para o conhecimento cumprir a sua função economica é indispensavel a inexistencia da minima duvida sobre a realidade das mercadorias por ele representadas.

Não é restringivel, nem modificavel a função do conhecimento. Prova-se, por ele, o recebimento e a obrigação de restituir. Antes, já havia o decr. n. 2.681, de 7 de dezembro de 1912, estabelecido a responsabilidade das estradas de ferro pela perda total ou parcial, roubo ou avaria das mercadorias que receberem para transportar. Levando adiante o seu rigorissimo, presumiu, sempre, a culpa da estrada. Contra essa presunção só admite alguma das seguinte provas:

a) de caso fortuito ou força maior;

b) de ter-se verificado a perda ou avaria:

1, por vicio intrinseco da mercadoria ou por causas inerentes á sua natureza;

2, tratando-se de animais vivos, em consequencia de risco que tal especie de transporte naturalmente corre;

3, devido ao máu acondicionamento da mercadoria ou a ter sido entregue sem estar encaixotada, enfardada oul protegida por qualquer outra especie de envoltorio;

4, por ter sido transportada em vagões descobertos, em consequencias de ajuste ou expressa determinação do regulamento;

c) de terem resultado de haverem sido feitos o carregamento e o descarregamento pelo remetente ou pelo destinatario ou pelos seus agentes;

d) de ter sido a mercadoria transportada em vagão ou platafórma especialmente fretado pelo remetente, sob a sua 
custodia e vigilancia e ter-se dado a perda ou avaria em consequencia do risco que essa vigilancia devia remover.

Eis a importancia do conhecimento e a latitude da obrigação da companhia ou empreza de transporte ferroviario. Não lhe é permitido restringi-la ou modifica-la. Nem fixar, senão facultivamente, o valor da indenisação a pagar, quando devida.

E' o disposto no art. 12 do decr. n. 2.681:

"A clausula de não garantia das mercadorias, bem como a prévia determinação do maximo da indenisação a pagar, nos casos de perda ou avaria, não poderão ser estabelecidos senão de modo facultativo e correspondente a uma diminuição de tarifa. Serão nulas quaisquer outras clausulas diminuindo a responsabilidade das estradas de ferro estabelecidas na presente lei".

Assim conceituado e formalisado, o conhecimento ferroviario, como o de qualquer outra empreza de transportes, poderá ser negociado, entrando na circulação economica. Mas na sua primeira via: a original. As outras não podem circular, sendo emitidas somente para efeitos em face da empreza emissora.

17. O CONHECIMENTO NÃO A' ORDEM. - Para esse efeito, considerou o decreto n. 19.473, de 10 de dezembro de 1930, o conhecimento como titulo á ordem, salvo quando emitido ao portador.

Deu-lhe o impulso inicial, deixando ao arbitrio e na conveniencia do remetente ou do consignatario introduzi-lo no mundo dos negocios, se á ordem, por endosso; se ao portador, pela simples tradição manual.

Permitiu o decr. n. 20.454, de 29 de setembro de 1931, entretanto, a emissão do conhecimento "não á ordem", mediante clausula expressa inserida no seu contexto. Com isso, creou uma nova modalidade: a do conhecimento não negociavel por via de endosso, destituido da qualidade de titulo de credito.

Poderá, sem embargo, ser transferido, mas pela fórma 
comum, por via de contrato de cessão e transferencia ou de compra e venda; e servir de garantia para uma operação. de credito, mas em razão de um contrato de penhor mercantil.

Simplificou, por isso mesmo, o processo da entrega da mercadoria ao consignatario, em caso de perda, destruição, furto ou roubo do conhecimento: far-se-á por segunda via ou certificado do despacho, de acôrdo com os regulamentos em vigor.

Se, todavia, a empreza tiver aviso de ter sido ele cedido ou apenhado, depositará a mercadoria por conta de quem pertencer.

18. AS MODALIDADES DO CONHECIMENTO. - Póde apresentar-se o conhecimento, portanto, sob duas modalidades:

I, o nominativo:

a) á ordem;

b) não á ordem;

II, o ao portador.

Isso, no momento da emissão. Na sua trajetoria até a entrega da mercadoria, poderá o nominativo converter-se em ao portador e este naquele.

\section{VII}

19. A TRANSFERENCIA DO CONHECIMENTO A' ORDEM. - O conhecimento nominativo á ordem é transferivel, sucessivamente, por endosso. Para a validade deste é suficiente a simples assinatura do proprio punho do endossatario ou de seu mandatario especial, no verso do titulo.

E' o endosso em branco, ou incompleto.

0 primeiro endossador deve ser o remetente, quando se indicar como consignatario, ou este. Mais seguramente se dirá deve ser o consignatario o primeiro endossante. 
Exarando-se com a indicação do nome do endossatario, por extenso:

Entregue-se ao sr. Antonio Garlos de Andrada.

São Paulo, 6 de dezembro de 1931.

Bento Gomes de Sá.

o endosso será completo: é o em preto. Contenha, ou não, a declaração de ter sido pago o preço, perfeitamente dispensavel, valido será, seja qual fôr a formula por que se exteriorize. Em vês da formula "entregue-se", que não é sacramental, poder-se-á servir de outra equivalente: "pertence ao sr.. ." por exemplo. Usualmente, ao verbo endossar, quando deva ser empregado, se prefere a locução "passar o pertence": é mais sugestiva, embóra menos tecnica. Denotam ambas as expressões o intuito de transferir a propriedade, subentendido na simples assinatura, de proprio punho, despida de qualquer indicação, constituinte do endosso, aposta pelo consignatario, mesmo quando o proprio remetente seja, no verso do conhecimento.

Endossar é, sem rodeios, transferir.

Deve, por isso, ser puro e simples o endosso. Qualquer clausula, que o modifique ou condicione, se não autorisada em lei, não escrita se reputa: é como se não existisse.

O endosso se efietua não apenas pela assinatura no verso do titulo, senão pela sua tradição ao endossatario, como adquirente.

$\mathrm{O}$ endosso parcial é nulo.

Não será licito ao consignatario de uma partida de vinte sacas de café, pelo haver vendido dez, lançar o endosso nestes termos :

Entreguem-se dez sacas ao sr. José Maria Gomes.

São Paulo, 8 de dezembro de 1931.

Olivio Gomes. 
Seria dificil á empreza ferroviaria cumprir a ordem de entrega. Para cumpri-la, teria de receber o conhecimento e, certamente, referindo-se ele a maior quantidade de sacas que as transferidas, não largaria dele o endossante.

A lei cortou a duvida pela raiz. Tal endosso é nulo. Não póde ser feito. Se fôr, inoperante será.

20. A TRANSFERENCIA DO CONHECIMENTO AO PORTADOR. - Se o conhecimento á ordem se transfere por endosso seguido da tradição manual, a transferencia do ao portador se opera simplesmente por via desta.

A mera tradição manual, refiere a lei, transfere o conhecimento ao portador e o endossado em branco, para o mesmo efeito.

Identico principio já se encontrava em nossa legislação, a proposito das ações ao portador emitidas pelas sociedades anonimas.

"A cessão das ações ao portador", eis o dispositivo do art. 24 do decr. n. 434, de 4 de julho de 1891, "se consuma pela simples tradição dos titulos. O portador da ação se presume dono, emquanto o contrario não fôr provado".

A mesma nórma se aplica ao conhecimento ao portador.

21. A CONVERSÃO DO CONHECIMENTO ,NOMINATIVO EM AO PORTADOR E A DESTE NAQUELE. - Muito facil é converter o conhecimento nominativo á ordem em conhecimento ao portador. Póde apresentar-se momento em que tal se torne vantajoso para o consignatario. Nem 'sempre convem ao comprador da mercadoria despachada /se saiba que a adquiriu. Nesse transe, para facilitar a circulação do titulo e o negocio em vista, não terá o consignatario outra cousa a fazer senão endossa-lo em branco.

$O$ endosso em branco faz o titulo circular ao portador até novo endosso.

Realisa-se, por essa fórma, a conversão.

Se, todavia, no seu giro, de tradição em tradição, chegar ás mãos de quem queira designar-se como endossatario, con- 
fere a lei ao portador poderes para preencher o ultimo endosso em branco. Sobre a firma do endossante, a mão, ou a maquina, escreverá :

\section{Entregue-se ao sr. Pedro Dias de Sá.}

\section{Voltará o conhecimento a ser nominativo.}

Impossivel é efetuar-se a conversão de um conhecimento não á ordem em conhecimento á ordem.

Muito mais em ao portador.

22. O CANCELAMENTO DO ENDOSSO. - A simples grafia do endosso não transfere o conhecimento. A transferencia se consuma pela tradição.

Lançado ele, bem pode fracassar o negocio que, com ele, se ultimaria. Nesse caso, ao endossante é permitido inutiliza-lo. Dar o feito por desfeito, o dito por não dito.

A inutilisação do endosso efetua-se pelo seu cancelamento. Basta riscar os dizeres, por que se tinha exarado. Ou a simples assinatura.

Cancelado o endosso, revogada ficou a transferencia.

Um efeito, no emtanto, e um unico, reconhece a lei ao endosso cancelado: o de justificar a serie das transmissões do titulo.

Para isso é habil.

23. OS EFEITOS DO ENDOSSO. - Mercê do endosso fica o endossatario equiparado ao consignatario. $O$ endossatario nominativo e o portador do conhecimento investemse nos seus direitos e nas suas obrigações, em face da empreza emissora.

Pode, exibindo-lho, reclamar as mercadorias por via dele despachadas. Tanto que lho apresente para recebe-las, deve ela entregar-lhas, sem lhe ser admitida oposição alguma. Não tem ação para investigar o direito por que o conhecimento lhe foi transferido. 
$\mathrm{E}$ isso pela razão ponderosissima de não operar o endosso simplesmente a transferencia do conhecimento senão tambem a da propriedade das mercadorias despachadas. Presume a lei ser o ultimo endossatario e detentor do conhecimento o seu proprietario.

O portador do conhecimento de transporte, mais precisamente acentua o art. 433 do projeto do codigo comercial, tem a livre disponibilidade das mercadorias e reputa-se dono delas emquanto o contrario não fôr provado. Terceiro não portador de alguma via do conhecimento, referiu no art. 434, não póde impedir a entrega da mercadoria a quem se apresenta como portador do conhecimento, salvo nos casos de embargo ou penhora, decretado por juiz competente contra o consignatario da mercadoria ou o portador do conhecimento nominativo ou endossatario dele. Reconheceu-lhe a livre disponibilidade e lhe presumiu a propriedade, até prova em contrario.

O decr. n. 19.473 exprimiu o mesmo pensamento por outras palavras, no art. 8:

"A tradição do conhecimento ao consignatario, ao endossatario ou ao portador, exime a respetiva mercadoria de arresto, sequestro, penhora, arrecadação, ou qualquer: outro embaraço judicial, por fato, divida, falencia, ou causa extranha ao proprio dono atual do titulo; salvo caso de má fé provada.

O conhecimento, porém, está sujeito a essas medidas judiciais, por causa que respeite ao respetivo dono atual. Neste caso, a apreensão do conhecimento equivale á da mercadoria".

Tal qual preceitua o art. 17 da lei n. 1.102, de 21 de novembro de 1903, a respeito do conhecimento de deposito de generos e mercadorias nos armazens gerais e do respetivo warrant. Esses titulos tambem forram as mercadorias depositadas de embargo, penhora, sequestro ou qualquer outro embaraço que prejudique a sua livre e plena disposição. Só eles e não elas podem ser penhorados ou arrestados por dividas do portador. 
Justificou J. X. Carvalho de Mendonça essa "especie de imunidade ou asilo mercantil", no ensinamento de ErCole VIDARI, "pela necessidade de animar o publico a servir-se da instituição que garante eficazmente o direito de propriedade; os credores pignoraticios, proprietarios e credores estarão certos de que, afóra em determinados casos, nenhum ato enfraquecerá os seus direitos" (16).

Vinculando, por essa fórma, ao conhecimento a carga por via dele despachada, deu-lhe a lei consideravel prestigio. A segurança do negocio, facilitada pela endossabilidade do titulo, quasi o transformou em uma letra de cambio ferroviaria.

Impedindo, por outro lado, a penhora, o arresto, o sequestro da mercadoria, depois da tradição do conhecimento ao consignatario, ao endossatario, ou ao portador por qualquer divida extranha ao seu dono atual e, mesmo, a sua arrecadação, em caso de falencia do remetente, a lei lhe deu singular prestancia.

Se, endossando-o, não se responsabiliza o consignatario solidariamente com os nele intervenientes, anterior ou posteriormente, como acontece com os coobrigados cambiarios, subsiste, entretanto, a responsabilidade do endossador pela legitimidade do titulo e pela existencia da mercadoria para com os endossatarios posteriores ou o portador.

Produz, portanto, o efeito da cessão civil.

E a ação, nele fundada, terá o curso sumario.

24. O ENDOSSO MANDATICIO. - Além desse efeito proprio, poderá ter o endosso os improprios, entre os quais o de conferir ao endossatario poderes afim de agir em nome e por conta do endossante.

A clausula de mandato, inserta no teôr do endosso em preto, faz o endossatario procurador do endossador, com to-

(16) J. X. Carvalho de Mendonça, Tratado de Direito Comercial Brasileiro, vol. 5, 2. ${ }^{\mathrm{a}}$ parte, pag. 707, n. 1.127; Ercole Vidari, Corso di Diritto Commerciale, vol. 4,5." ed., n. 4.024. 
dos os poderes gerais e especiais relativos ao titulo, salvo restrição expressa, constante do mesmo teôr. Se clausula identica, lançada no endosso da letra de cambio ou da nota promissoria, nos termos do art. $8, \S 1$, do decr. n. 2024, de 31 de dezembro de 1908, indica o mandato "com todos os poderes", o do conhecimento confere "poderes gerais e especiais relativos ao titulo", poderes mais amplos.

Como mandatario, é o endossatario, portanto, obrigado a praticar todos os atos conservativos, a apresentar o conhecimento na estação de destino, a receber a mercadoria e a guarda-la, prestando todos os cuidados necessarios á sua conservação e defesa e cumprindo todas as instruções do endossante, sob pena de responder por perdas e danos.

Exprime-se esse endosso pela clausula dele indicativa: "por procuração", ou abreviadamente: "p. p."

Assim :

Entregue-se, por procuração, ao sr. Francisco da Silveira ou:

Entregue-se ao Banco do de São Paulo, meu procurador ou, ainda

Entregue-se a A. Ferreira \& Cia., em consignação

Não exigiu a lei, sacramentalmente, a clausula “p. p.". Qualquer formula a exteriorizará, desde que implique o mandato (17.) De tal modo se tem entendido o texto similar da lei cambiaria e outra interpretação lhe não deu a convenção internacional para unificação do direito relativo á letra de cambio e á nota promissoria, celebrada em Haia, em 23 de agosto de 1912, aprovada pelo decr. n. 3.756 , de 27 de agosto de 1919 .

17. Waldemar Ferreira, Manual do Comerciante, 3." ed., pag. 149 , n. 87. 
E o substabelecimento do mandato pode dar-se mediante novo endosso, de igual especie.

25. O ENDOSSO PIGNORATICIO. — Não teve o endosso jamais por efeito, em face de nossas leis, senão transferir a propriedade dos titulos de credito ou conferir mandato para a sua execução ou cobrança. Desconheciam elas o endosso pignoraticio. Sem embargo de ter angariado adeptos de renome, ele desqualificava $o$ ato.

Coube ao decr. n. 19.473 introduzir em nosso sistema juridico o endosso pignoraticio. Tem, pois, o endosso do conhecimento de transporte um efeito proprio: o de transmitir a sua propriedade e a das mercadorias nele declaradas; e dois efeitos improprios: o de conferir ao endossatario poderes de procurador do endossante e o de converte-lo em seu credor pignoraticio. 0 mandato resultará de clausula que o implique. A caução, de clausula expressa, consoante o $\S$ unico do art. 4:

"Lançada a clausula de penhor ou garantia, o endossatario é credor pignoraticio do endossador".

Converte, portanto, o endossatario em credor pignoraticio, como depositario obrigado, na conformidade do art. 774 do codigo civil:

a) a empregar na guarda do penhor a diligencia exigida pela natureza da cousa;

b) a entrega-lo, com os respetivos frutos e accessões, uma vês paga a divida;

c) a entregar o que sobeje do preço, quando a divida fôr paga, seja por excussão judicial, ou por venda amigavel, se lha permitir, expressamente, o contrato, ou lha autorizar o devedor, mediante procuração especial;

d) a resarcir ao dono a perda ou deterioração, de que fôr culpado.

Retirando a mercadoria, na estação de destino, poderá, ainda, o endossatario deposita-la, com a mesma clausula 
procuratoria, em armazem geral, ou senão onde convier, de acôrdo com o endossador.

Poderá, ademais, nesse caso, a todo o tempo, exigir ao emprezario do armazem geral a emissão do respetivo conhecimento de deposito e o warrant, ficando aquele á livre disposição do dono da mercadoria e este á do credor pignoraticio, para ser-lhe entregue depois de devidamente endossado.

Se o devedor pignoraticio se recusar a endossar o warrant, ficará sujeito á pena de multa de importancia correspondente a dez por cento $(10 \%)$ do valor da mercadoria, em beneficio do credor.

Sobre a mercadoria, esclarece a lei, depositada com clausula de penhor ou de garantia, somente se expedirão tais titulos, mediante consentimento do credor, que se não poderá opôr, desde que se the ofereça o respetivo warrant.

Receberá ele, em tais condições, titulo de credito, de igual senão de maior valia. Não é obrigatorio o seguro das mercadorias despachadas por via ferrea contra os riscos de incendio e outros. As mercadorias, depositadas em armazens gerais, entretanto, para servirem de base á emissão dos titulos respetivos, deverão ser seguradas contra riscos de incendio, pelo valor designado pelo depositante. Poderão os armazens gerais, para isso, ter apolices abertas ou especiais.

A medida é, portanto, salutar.

Para adquirir o endosso, entretanto, o carater pignoraticio, exige a lei apenas a clausula de penhor ou garantia. Mas o penhor, como direito real de garantia, é accessorio: não existe sem a divida a que adira e garanta.

Nasce a divida de uma convenção, verbal ou escrita. O contrato de penhor, o por que, reza o art. 271 do codigo do comercio, o devedor, ou um terceiro por ele, entrega ao credor uma cousa movel em segurança e garantia de obrigação comercial, só póde provar-se por escrito assinado por quem recebe o penhor. $\mathrm{E}$ o escrito, acrescenta o art. 272, deve enunciar, com toda a clareza, a quantia certa da divida, a causa de que precede, e o tempo do pagamento, a qualidade do penhor, e o seu valor real ou aquele em que fôr estima- 
do: não se declarando o valor, se estará, no caso do credor deixar de restituir ou de apresentar o penhor, quando fôr requerido, pela declaração jurada do devedor.

Ora, pela simples clausula de penhor ou de garantia, lançada no endosso do conhecimento, ficam vinculadas as mercadorias por ele representadas ao pagamento de uma divida. Mas de que importancia? E qual a epoca de seu pagamento? E quais os juros devidos?

Não articulou a lei nenhuma palavra a respeito. Permitiu apenas o endosso pignoraticio, cujas formalidades devera ter enumerado, como o fiez o decr. n. 1.102, de 21 de novembro de 1903, no art. 19, acerca do endosso do warrant, que tem a mesma natureza :

“O primeiro endosso do warrant declarará a importancia do credito garantido pelo penhor da mercadoria, a taxa dos juros e a data do vencimento.

Essas declarações serão transcritas no conhecimento de deposito e assinadas pelos endossatarios do warrant".

E' de bôa hermeneutica aplicar esse dispositivo ao endosso pignoraticio do conhecimento, salvo a existencia de contrato escrito, em separado, em que se haja constituido a divida, estipulado os seus juros e marcado o prazo de seu vencimento.

Endossar-se-á, pois, o conhecimento seguindo esta ou outra fórmula identica:

Entreguem-se ao sr. Paulo Pinto, em garantia da importancia de Rs. 25:000\$000, que dele recebi e que lhe pagarei no dia 30 do corrente, com os juros de dez por cento (10\%) ao ano. - São Paulo, 13 de dezembro de 1931.

MANUEL RABELLO

Assim deve ser modelado.

Consistindo a cousa empenhada em titulos de credito, entende o art. 277 do codigo do comercio o credor subrrogado pelo devedor para praticar todos os atos necessarios 
para a conservação e validade dos titulos e os direitos do devedor, ao qual ficará responsavel por qualquer omissão de sua parte. E é, igualmente, competente para cobrar o principal e creditos do titulo empenhado em sua mão, sem ser necessario poderes especiais ou gerais do devedor. Se essas são as suas obrigações, já anteriormente desdobradas em outros enunciados, assiste-lhe a da entrega imediata do penhor desde que o devedor se ofereça a remi-lo, pagando a divida ou consignando o preço judicialmente. Como exercerá o endossante, como devedor, esse direito se, do proprio conhecimento, e dada a inexistencia de documento em separado comprobatorio da divida, não constar a importancia da divida?

Não poderá o endossatario pignoraticio, como é obvio, reendossar o conhecimento. 0 credor, reza o art. 276 do codigo do comercio, que recebe do seu devedor alguma cousa em penhor ou garantia, fica, por esse fato, considerado verdadeiro depositario da cousa recebida e sujeito a todas as obrigações e responsabilidades pertinentes aos depositarios.

Licito lhe não será, consequentemente, transferi-lo por novo endosso.

\section{VIII}

26. O DESEMBARQUE E A ENTREGA DA MERCADORIA EM TRANSITO. - Permite o regulamento dos transportes ferroviarios ao expedidor modificar o despacho, ou torna-lo sem efeito, estando o conhecimento em seu poder e encontrando-se a carga, embora já despachada, ainda na estação de procedencia. Restituirá á estrada de ferro, nesse caso, os documentos existentes em seu poder. Tornado sem efeito o despacho, receberá a carga, mais a importancia do frete pago, entrando, todavia, com a das taxas de carga e descarga. Modificada a consignação, cobrará a estação despachante a diferença ou restituirá o excesso do frete, 
se tiver sido pago e estiver em divergencia com o novo despacho, substituindo o conhecimento.

A variação de destino ou de consignatario, portanto, somente se realizará antes da partida do trem de carga e na estação de procedencia.

Trouxe a lei, neste particular, uma inovação.

E' a do art. 7:

"O remetente, consignatario, endossatario ou portador póde, exibindo o conhecimento, exigir o desembarque e a entrega da mercadoria em transito, pagando o frete por inteiro e as despezas extraordinarias a que der causa. Extingue-se, então, o contrato de transporte e recolhe-se o respetivo conhecimento.

$O$ endossatario em penhor ou garantia não goza dessa faculdade".

Tinha já o art. 113 do codigo de comercio previsto a variação da consignação pelo carregador e imposto ao condutor ou comissario de transportes a obrigação de cumprir a ordem neste sentido, recebendo-a antes de feita a entrega da carga no lugar do destino. Sobre assistir ao carregador o direito de dispôr dela, não ha para o condutor alteração substancial nas condições principais do ajuste, sendo-lhe indiferente entrega-la a uma ou outra pessôa, o que, agora, com frequencia, acontece, em face da endossabilidade do conhecimento á ordem ou ao portador. Não somente isso previra o velho codigo, senão tambem a variação do destino da carga. Prevendo-a, estàbeleceu que se a variação do destino da carga exigir a variação de caminho, ou que o condutor passe do primeiro lugar destinado, este tem direito de entrar em novo ajuste de frete ou aluguel, e, não se acordando, só será obrigado a efetuar a entrega no lugar designado na cautela ou recibo.

$\mathrm{O}$ decr. n. 19.473, porém, além dessas duas hipoteses, previu a da suspensão do transporte da mercadoria em transito e a da sua imediata entrega, entre a estação de procedencia e a de destino, ao remetente, consignatario, endossatario ou portador do conhecimento. 
27. O INSTITUTO DO "STOPPAGE IN TRANSITU". -Teve ele, com tal disposição, o intuito de resolver qualquer duvida relativa á aplicação, entre nós, do instituto do direito inglês, conhecido por stoppage in transitu?

Teve-o, ao parecer de Paulo de Lacerda:

"O Tribunal de Justiça de São Paulo, com votos vencidos de diversos dos seus mais conspicuos membros, ha pour cos anos aplicou esse instituto exotico de maneira desastrada, permitindo que certo remetente se apoderasse de mercadoria cuja tradição já havia feito mediante entrega dos respetivos titulos representativos, inclusivé o conhecimento. $\mathrm{O}$ decreto só admite a faculdade, que tal instituto contem, ao dono atual do conhecimento ou seu mandatario, denegandoa expressamente ao endossatario por penhor, que não é dono da mercadoria, aliás empenhada já com o destino certo constante do titulo" (18).

18. Paulo de Lacerda, Conhecimentos de fretes, em o Arquivo Judiciario, vol. 17, pag. 15, suplem.

- Os adquirentes de uma partida de algodão haviam-na revendido, transferindo os respetivos conhecimentos e documentos maritimos ao comprador. Logo depois, e aquela mercadoria já se achava em processo de despacho, na Alfandega de Santos, os revendedores convocaram os seus credores afim de lhes propor uma concordata preventiva. Nesse transe, sem embargo do art. IV, da lei n. 2024, de 17 de dezembro de 1908, então em vigor, mas reproduzido no decr. n. 5.746, de 9 de dezembro de 1929, impossibilitar, expressamente, a reivindicação, então somente na falencia admissivel, das mercadorias "que o falido, antes da falencia, revendera sem fraude, á vista das faturas ou conhecimento de transporte, entregues ou remetidas pelo vendedor, embora tais mercadorias não tivessem chegado efetivamente ao poder do mesmo falido, seu agente ou comissario", os vendedores requereram ao juiz processante da concordata mandasse oficiar á Alfandega, determinando-lhes a entrega do algodão. 0 juiz, sem fórma, nem figura de juizo, sumarissimamente, mandou entregar. E - Tribunal de Justiça de São Paulo confirmou a decisão, por estes acórdãos :

I

Vistos, relatados e discutidos os presentes autos de apelação n. 14.432, desta capital, entre partes, apelantes N. Barros \& Cia. e 
Assiste, efetivamente, no direito ìnglês, em caso de insolvabilidade do comprador ao vendedor a faculdade de fazer parar a mercadoria em transito, right of stoppxge in transitu, e de apossar-se dela. E' um verdadeiro direito de sequela, expressão pela qual traduziu Correa Teles o droit de suite dos francêses, adotada pela lei portuguêsa de 1 de julho de 1863 .

apelados José de Vasconcelos \& Cia., acórdão em Tribunal de Justiça, por maioria de votos, negar provimento á apelação e confìmar, como confirmam, a sentença apelada, por seus fundamentos, que estão confórme o direito e de acôrdo com as provas.

Verifica-se na hipotese o caso previsto no art. 198 do codigo comercial. A mercadoria em transito ainda estava sob as ordens dos remetentes, quando foi retida. Dada a mudança de estado dos compradores, que requereram concordata, desaparecera a obrigação da entrega real da mercadoria. Para a retenção não se faz preciso a posse material do objeto, basta a faculdade de disposição. Este direito é do remetente, emquanto os objetos estão sendo transportados para entrega. A venda pela fatura, ás pressas, por menos do preço, foi uma $\backslash$ medida pretensamente salvadora de que lançaram mão os compradores, mas não mudou a face da questão.

Não ha razão para que se reforme a sentença apelada. Custas pelos apelantes.

São Paulo, 5 de outubro de 1926. - PINTO DE TOLEDO - G. MESQUITA, relator ad hoc. - PHILADELPHO CASTRO -- COSTA E SILVA, vencido.

\section{II}

Acórdam em Tribunal, vistos, relatados e discutidos estes autos da comarca da Capital, em que são embargantes N. Barros \& Cia. e embargados J. Vasconcelos \& Cia., regeitar os embargos de fls. 168 e confirmar o acórdão embargado, que decidiu com todo o acerto e justiça a especie em debate.

E, com efeito, o algodão comprado pelos embargantes aos embargados e por estes embarcado no porto de Recife com destino a Santos, achava-se ainda em transito: não tinha sido entregue real e efetivamente aos compradores, que, antes de pagarem o preço da mer cadoria comprada, revenderam-na á vista dos conhecimentos e requereram no dia seguinte concordata preventiva para pagamento de $50 \%$ aos seus credores, em duas prestações.

Os compradores mudaram, assim, notoriamente de estado, verificando-se então a hipotese do art. 198 do codigo comercial, de sorte 
Exercita-se tal direito de sequela pela notificação feita pelo vendedor ao transportador ou á pessôa em cujo poder se encontre a mercadoria vendida, da intenção de exercelo. E o transportador fica, diante dela, obrigada a entregala ao rendedor, que suportará as despezas.

Da sua legitimidade decidiu o Supremo Tribunal Federal, por acórdão de 29 de novembro de 1924. Tendo companhias inglêsas fabricantes de ferro e de aço fornecido elevado numero de toneladas de trilhos de aco, de talas e demais accessorios para vias ferreas a uma companhia, tambem inglêsa, que exercia a sua atividade no Piauí, mediante o ajuste do pagamento do preço em Londres, com a apresentação dos documentos comprobatorios do embarque da encomenda, manifestou-se a insolvencia da compradora antes da chegada dos materiais comprados ao porto de Parnaíba, que era o do destino. Deram as vendedoras á companhia de transporte a ordem de não entrega dos materiais, que foram recebidos pela Alfandega, ficando aí depositados. Apoderou-se deles, afinal, o governo brasileiro e o Supremo Tribunal, reconhecendo a legitimidade do stoppage in transitu,

que os vendedores não eram obrigados a entregar a cousa vendida, podendo exercer sobre ela o direito de retenção, como o fizeram legal e juridicamente por autoridade de justiça e como medida acauteladora de seus direitos, não havendo motivo algum para se concluir pela nulidade do processo.

Custas pelos embargantes.

São Paulo, 22 de fevereiro de 1927. - URBANO MARCONDES, P. - POLYCARPO DE AZEVEDO JUNIOR, relator designado - LUIZ AYRES - GODOY SOBRINHO - COSTA E SILVA, vencido - ELISEU GUILHERME, vencido - G. MESQUITA - PHILADELPHO CASTRO.

(Revista dos Tribunais, vol. 65, pags. 341 a 349 ).

- NoÉ Azevedo, Do stoppage in transitu no direito brasileiro, na Revista dos Tribunais, vol. 57, pags. 421 a 469; Haroldo Valladão, Direito de retença da mercadoria vendida se o comprador muda notoriamente de estado antes da entrega real e efetiva. São Paulo, 1928. 
o condenou a pagar ás vendedoras a indenisação das perdas e danos (19).

Ordena o vendedor, no direito inglês, por via de uma notificação ao transportador terrestre ou maritimo a não entrega da mercadoria vendida ao comprador, cujo estado seja de insolvencia. Basta essa modificação, feita até por via telegrafica para sustar a entrega.

Argumenta um tratadista:

"Como, em direito inglês, o vendedor, quando se não reservou o direito de disposição ao expedir a cousa, não é mais proprietario (contrariamente ao direito alemão, segundo o qual o vendedor permanece proprietario até ao momento em que o comprador tenha retirado o titulo de disposição, o conhecimento, o recibo de deposito, etc.) tem o vendedor inglês necessidade de uma proteção particular em caso de insolvencia do comprador. Extingue-se o direito de sequela, em direito inglês, pela entrega das mercadorias ao comprador, se o vendedor não houver antes declarado por aviso ao transportador querer exerce-lo. A simples insolvencia do devedor basta para dar ao credor o direito de exercitar o right of stoppage. Ao contrario, o direito alemão exige a abertura da falencia" (20).

De outro modo não doutrinou J. X. Carvalho de MendonçA, em topico bastante expressivo:

" $O$ vendedor não pago, no caso de falencia ou de insolvencia do comprador, tem o direito de rehaver a posse das mercadorias expedidas (to resume possession of goods) se consegue obte-las ainda em viagem (while they are on their way). Supõe-se que a mercadoria se acha em viagem emquanto está em mãos do comissario de transporte e não chegou na posse efetiva ou artificial do comprador: until they

19. Revista Forense, de Belo Horizonte, vol. 45, pag. 27; Revista dos Tribunais, vol. 57, pags. 181 a 206.

(20) Arthur Curti, Manuel de Droit Comercial Anglats, pag. 169 . 
arrive at the actual or constructive possession of the consignee.

O right to stop in transitu exercita-se não por meio de efetivo embargo das mercadorias em caminho, mas por simples notificação ao carregador ou á pessôa em cujas mãos se acha para que as retenha; se por erro é entregue ao comprador, o vendedor póde rehave-las daquele e o carregador, que depois da notificação fez a entrega, responde por perdas e danos. SMITH'S, Mercantile law, pag. 695" (21).

28. A INEXISTENCIA DO "STOPPAGE IN TRANSITU” NO DIREITO BRASILEIRO. - Se, antes da expedição do decr. n. 19.473, não existia, no direito brasileiro, o instituto do stoppage in transitu, depois dele tambem não existe.

Dele difere, e muito, o desembarque e a entrega da mercadoria em transito.

Aquele se torna em realidade em razão de um simples aviso, telegrafico ou radiografico, do vendedor da mercadoria despachada á empreza de transportes. Como direito de sequela, compete ao vendedor. Não tendo sido pago do preço, pode rehaver a posse das mercadorias, que vendeu, se ainda em transito.

Este não se efetua com tal simplicidade. Compete ao remetente, ao consignatario, ao endossatario, ao portador. Qual deles estiver de posse titulada do conhecimento poderá exigir o desembarque e a entrega da mercadoria em transito. Mas exibindo o conhecimento. Não por simples aviso telegrafico ou radiografico.

Nenhum juiz, por conseguinte, sem a apresentação do conhecimento, poderá ordenar á empreza de transportes a entrega da mercadoria. Nem a em transito. Nem a chegada á estação de seu destino.

A lei a isso se opõe, em termos rispidos:

"A tradição do conhecimento", lê-se no art. 8, "ao consignatario, ao endossatario ou ao portador exime a respetiva

(21) J. X. Carvalho de Mendonça, Tratado de Direito Comercial Brasileiro, vol. 8, pag. 300 , em nota. 
mercadoria de arresto, sequestro, penhora, arrecadação ou qualquer outro embaraço judicial, por fato, divida, falencia ou causa extranha ao proprio dono atual do titulo, salvo caso de má fé provada.

$\mathrm{O}$ conhecimento, porém, está sujeito a essas medidas judiciais, por causa que respeite ao respetivo dono atual. Nesse caso, a apreensão do conhecimento equivale á da mercadoria".

Perfeita a venda, fica o vendedor obrigado pelo art. 197 do codigo do comercio a entregar ao comprador a cousa vendida no prazo e pelo modo estipulado no contrato, sob pena de responder pelas perdas e danos de sua falta resultantes. Não procede, porém, essa obrigação, obtempera o art. 198, antes de efetuado o pagamento do preço, se, entre o ato da venda e o da entrega o comprador mudar notoriamente de estado e não prestar fiança idonea ao pagamento nos prazos convencionados.

Expedida a mercadoria pelo vendedor, indicando o nome do comprador como consignatario e operada a tradição do conhecimento, entregue fica ela. Representa-a o conhecimento. Entrega real e efetiva, pelo presumir-se a sua propriedade e ter-lhe ele a sua disponibilidade.

Se o direito do vendedor inglês é o de sequela, o do brasileiro é o de retenção, garantido pelo art. 93 do decr. n. 5.746, de 9 de dezembro de 1929, salvo a resolução do contrato.

A diferença é sensivel.

Realiza-se o direito de sequela por ação. E o de retenção por inatividade. Mercê daquele pode o vendedor rehaver a posse da cousa expedida ao comprador, emquanto estiver sendo transportada: the right of the unpaid vendor to regain possession of the goods while they are being transported to the buyer. O direito do retentor, entretanto, é o de não largar a posse, o de nela se manter a todo transe, dela não renunciando. Pelo haver o comprador ou convocado os seus credores afim de lhes propôr uma concordata preventiva ou pelo lhe ter sido aberta a falencia, ao vendedor não assistirá o direito de avisar á companhia de transpor- 
tes a sua intenção de não deixar chegar a cousa vendida ás mãos do comprador. Poderá, sim, apresentar a sua reclamação reivindicatoria, num e no outro caso, pois o decr. $n$. 5.746 , de 9 de dezembro de 1929 , autoriza a reivindicação, na concordata preventiva ou na falencia:

a) das cousas não pagas integralmente, expedidas pelo vendedor ao concordatario ou falido, emquanto lhes não chegarem ao seu poder, de seu agente ou comissario, salvo se tiverem sido revendidas, antes da concordata ou da falencia, sem fraude, á vista das faturas ou conhecimentos de transportes, embóra, remetidas pelo vendedor, não tenham ao poder do falido ou do concordatario chegado, ou de seu agente ou comissario;

b) das cousas vendidas a credito nos quinze dias anteriores ao requerimento da concordata preventiva ou á declaração da falencia, se ainda se encontrarem em poder do devedor;

c) das cousas vendidas a credito nos quarenta dias anteriores ao requerimento da concordata preventiva ou á declaração da falencia, se ainda se encontrarem em poder do devedor, tendo sido o vendedor induzido por dolo ou fraude do mesmo devedor.

$\mathrm{O}$ direito de sequela, força é convir, posto em ação por via do stoppage in transitu, muito se distancia, pelo seu fundamento e pelo seu processo, da reclamação reivindicatoria.

\section{IX}

29. A PERDA OU EXTRAVIO DO CONHECIMENTO NÃO A' ORDEM. - Simples o processo de entrega da mercadoria em caso de perda ou de extravio de conhecimento não á ordem. Requererá o remetente segunda via deste ou simples certificado do despacho, de acôrdo com os regulamentos em vigor; e diante dele a empreza lhe entregará a mercadoria. 
Se, entretanto, tiver ela aviso de cessão ou penhor do conhecimento, depositará a mercadoria por conta e risco de quem pertencer.

Nesse caso, o remetente, nos autos do deposito, fará a prova da perda ou extravio do conhecimento original e da ausencia de penhor.

Bem assim de não o haver cedido a ninguem.

Esta prova negativa não é muito facil.

Determina 0 art. 4, n. II, da lei n. 4.827 , de 7 de fevereiro de 1924 , reproduzido no art. 134 , a), n. II, do decr. n. 18.542 , de 24 de dezembro de 1920 , a transcrição, no registro de titulos e documentos, dos contratos "de penhor comum sobre cousas moveis, feito por instrumento particular, nos termos do art. 771 do codigo civil".

Não existe, todavia, registro identico para os contratos particulares de penhor mercantil.

30. A PERDA OU EXTRAVIO DO CONHECIMENTO A' ORDEM. - Em caso de perda ou extravio do conhecimento á ordem ou ao portador, dará o interessado aviso disso á empreza de transportes, na estação do destino, para que retenha a respetiva mercadoria.

Sendo o aviso feito pelo remetente ou pelo consignatario, ela anunciará o fato, tres veses consecutivas, pela imprensa do lugar do destino ou da localidade mais proxima, se ali não existir, ou da capital do Estado. Não aparecendo reclamação, relativamente á propriedade ou a penhor do conhecimento, durante os dias do anuncio e mais os dois imediatos, será entregue a mercadoria ao notificante.

Provindo de outrem o aviso, requererá ele á empreza de transportes certidão do conhecimento, se não tiver sido emitido em mais de uma via. De posse desse documento, promoverá uma justificação do fato e do seu direito, no fôro da comarca do lugar do destino, com intimação do orgão do Ministerio Publico. Feita a justificação, publicar-se-á o aviso, por editais, tres veses consecutivas, na imprensa local, na mais proxima localidade ou na capital do Estado, se 
naquelas não houver. Afixar-se-ão, ademais, como de costume. Se, no logar, existirem Bolsa de Mercadorias e Camara Sindical de Corretores, far-se-á publico pregão e aviso a quem possa interessar.

Findo o prazo, aguardar-se-ão mais quarenta e oito horas.

Não surgindo oposição ou contestação, o juiz proferirá sentença nas subsequentes quarenta e oito horas e, uma vez transitada em julgado, poderá ordenar a expedição de mandado de entrega da mercadoria ao reclamante.

Aparecendo oposição ou contestação, marcará o juiz o prazo de cinco dias para a prova, findos os quais arrazoarão as partes, no prazo de dois dias, cada uma. E os autos serão conclusos ao juiz para proferir a sua sentença, dentro em cinco dias.

Da sentença, tenha ou não havido oposição, caberá agravo de petição, com fundamento no art. 9 , $\S 5$, do decr. $n$. 19.473 , de 10 de dezembro de 1930 , com as modificações feitas pelo decr. n. 19.754, de 18 de março de 1931 .

Todos os prazos judiciais correrão em cartorio, independentemente de assinação em audiencia.

Durante o processo da oposição, nos termos expostos, poderá a empreza requerer o deposito da mercadoria, por conta de quem pertencer, bem assim quando não retirada em tempo e nos mais casos previstos no regulamento geral dos transportes ou na lei.

A exibição do conhecimento original suspenderá as diligencias judiciais ou extrajudiciais, continuando o titulo a produzir plenamente todos os efeitos que lhe são proprios.

\section{A ENTREGA DA MERCADORIA INDEPENDENTE-} MENTE DO CONHECIMENTO. - Caso existe, todavia, da entrega da mercadoria despachada, independentemente de apresentação do respetivo conhecimento: é o das de valor até um conto de réis. 
Podem elas ser retiradas, independentemente do conhecimento, mediante as cautelas instituidas nas leis ou regulamentos em vigor.

Não tendo sido o seu valor declarado na ocasião do despacho, ficará a sua estimativa ao prudente arbitrio da empreza de transportes, no momento da entrega da mercadoria.

\section{$\mathbf{X}$}

32. A RETROATIVIDADE DA LEI SOBRE O CONHECIMENTO DE TRANSPORTES. - Fixando o inicio de sua vigencia no dia de sua publicação, ajuntou o decr. n. 19.473, ao seu art. 11, este paragrafo unico:

“Os conhecimentos de frete de transportes terrestres já expedidos antes deste decreto, segundo estilo do lugar da emissão, consideram-se plenamente validos e gozam das regalias outorgadas neste mesmo decreto, embora haja ação, ou execução ainda pendente".

Qual o sentido do texto? Teria validado todos os conhecimentos e, principalmente, todos os contratos com eles anteriormente celebrados? Estabelecendo o endosso pignoraticio, por exemplo, quando exarado expressamente na clausula de penhor ou de garantia, validos ficaram os endossos anteriores seim essa clausula, mas para o mesmo efeito?

Respondeu Paulo de Lacerda afirmativamente:

"O art. 11 do decreto valida plenamente, para todos os efeitos, os conhecimentos de frete terrestre (só estes), passados de acôrdo com o estilo do lugar da emissão, obstando, assim, a que se consumem execuções judiciais, porventura já em andamento, baseadas na insuficiencia ou interpretação do direito anterior.

A' primeira vista póde parecer chocante essa disposição, perfeitamente cabivel por partir do governo revolucionario cujo chefe está plenamente investido em poderes discrecionarios; mas, devéras, devo reconhecer que a inspiron um sincero e digno sentimento de justiça social. Em mo- 
mentos historicos, como o que ora atravessa a nossa Patria, muito louvavel é que renasça aquele belo e brilhante espirito de humanidade, que, com aequitas temperando o jus strictum, formou o jus praetorianum, construindo o maior monumento da sabedoria juridica de todos os tempos, o direito romano das Pandectas e da Instituta, no maior imperio da historia, o mundo romano.

Esse formoso espirito, orientando o decreto, se não podia conformar com a insidia dos que arguiam, ou viessem a alegar, questão de mero direito positivo para tirar proveito do erro que, porventura, houvesse cometido em comum com as partes com as quais transacionaram. O decreto, considerando que todas as operações realizadas já sobre conhecimentos de frete, emitidos segundo o estilo do lugar da emissão, efetivamente se devem estimar feitas em bôa fé, as põe a coberto das investidas, ainda não plenamente consumadas, da má fé de qualquer dos operantes. E essas investidas estavam se efetuando, vindo a noticia para a imprensa e levada ao conhecimento do governo pelas vitimas da esperteza. Já o grande CICERO dizia que justitia creditiis in rebus fides nominatur (De Part. Orat., 22).

$\mathrm{O}$ dispositivo do art. 11 não atinge os direitos consumados, qual diz explicitamente no final do texto. No que concerne ao canon da irretroatividade, isto é, dos efeitos da lei nova sobre os direitos adquiridos no imperio da anterior, ele apenas dá vigor aos conhecimentos passados de acôrdo com o estilo comum e, pois, a pratica já aceita de bôa fé e contra a qual só consciencias inescrupulosas se levantam atraidas pela ancia do lucro. $\mathrm{O}$ ato do governo inclina-se, como os editos dos Pretores de Roma, diante da equidade, da bôa fé, da naturalis ratio, para manter precisamente aqui, lo que foi livremente convencionado e não permitir que uma parte se locuplete á custa da outra em virtude de erro comum" (22).

(22) Paulo de Lacerda, Conhecimentos de frete, no Arquivo Judiciario, vol. 17, pag. 15, suplem. 
Manteve a Segunda Camara do Tribunal de Justiça de São Paulo, por acórdão de 24 de julho de 1931, sentença de um dos juizes da comarca de Santos, por via da qual se decidira pela aplicação retroativa do decr. n. 19.473, de 10 de dezembro de 1931, e dando-se como validos endossos pignoraticios realisados em completo antagonismo com os seus proprios dispositivos (23).

33. O SENTIDO DO TEXTO LEGAL. - Nem aquela pagina de doutrina, nem esta de jurisprudencia, bem é de ver, exprimem a verdade juridica.

Considerando os conhecimentos de frete de transportes terrestres, até então expedidos, segundo o estilo do lugar da emissão, plenamente validos, o decreto ditatorial o focalizou, sem duvida, no momento da emissão, se não revestido das formalidades por ele mencionadas. 0 nome, ou a denominação da empreza emissora. 0 numero de ordem. A data, com indicação de dia, mês e ano. Os nomes do remetente e do consignatario, por extenso, podendo o remetente designar-se como consignatario e a indicação deste substituirse pela clausula ao portador. O logar da partida e do destino. A especie e a quantidade ou peso da mercadoria, bem como as marcas, os sinais exteriores dos volumes da embalagem. A importancia do frete, com a declaração de ser pago ou a pagar e do logar e da fórma do pagamento. A assinatura do emprezario ou seu representante, abaixo do contexto.

Se o conhecimento foi emitido sem algumas dessas formalidades, exigidas, como substanciais, pela lei nova; se, todavia, na sua emissão, se observaram as prescrições do estilo "no logar da emissão", plenamente valido ficou, passando a gozar das regalias por ela outorgadas.

Esse conhecimento, assim emitido, poderia, de então em diante, ser endossado, como se fosse um titulo emitido de acôrdo com a lei nova.

(23) Revista dos Tribunais, vol. 79, pag. 317. 
Nem se pense ter o governo provisorio extinguido os direitos adquiridos, menosprezado os atos juridicos perfeitos ou posto á margem as cousas julgadas, subvertendo, por completo, a ordem juridica estabelecida.

Quem assim pensasse estaria em erro.

Exercendo, discrecionariamente, em toda a sua plenitude, as funções e atribuições, não só do poder executivo, como, tambem, do poder legislativo, ele se impôs certas nórmas, que colocaram o paiz numa como que vida constitucional provisoria. E isso fez por via do decr. n. 19.398, de 11 de novembro de 1930, cujo art. 6 preceituou continuarem "em inteiro vigor e plenamente obrigatorias, todas as relaçôes juridicas entre pessôas de direito privado, constituidas na fórma da legislação respetiva e garantidos os respetivos direitos adquiridos".

Não se solucionou a ordem civil. Subsistiram em plena eficacia as relações juridicas de direito privado. Quem era casado casado ficou. O devedor continuou a dever. Ao proprietario assegurou o que era seu. Não se desfizeram as obrigações.

Nem tudo se transfigurou ao toque revolucionario. Quem tinha direitos adquiridos, na posse deles permaneceu. Não se desfalcou o seu patrimonio.

Ora, no estado anterior ao advento revolucionario, o conhecimento de transporte ferroviario não representava a mercadoria despachada. Não era titulo de credito, cuja transferencia, por via de endosso, importasse a transferencia da propriedade da mercadoria em viagem. A caução do conhecimento, por via de endosso, sem clausula de penhor ou de garantia, não vinculava a mercadoria.

Tanto não era assim, que o governo provisorio se viu na necessidade de disciplinar a materia, mas sem ofender os direitos já adquiridos. Teve ele por intuito garanti-los.

Por isso, no art. 8 do seu decreto institucional, esclareceu não se compreenderem nos direitos privados, por ele assegurados, podendo ser anulados ou restringidos, coletiva ou individualmente, por atos ulteriores, "os direitos até aqui re- 
sultantes de nomeações, aposentadorias, jubilações, disponibilidades, refórmas, pensões, ou subvenções e, em geral, todos os atos relativos a empregos, cargos ou oficios publicos, assim como o exercicio ou desempenho dos mesmos, inclusivé, e para todos os efeitos, os da magistratura, do ministerio publico, oficios de justiça e quaisquer outros", federais, estaduais ou municipais.

Os direitos adquiridos, na fórma do direito privado, ficaram de pé.

Não existia, em nosso direito, o chamado endosso pignoraticio. Nem de cambiais. Nem de conhecimentos. Tinha o endosso por efeito, propriamente, transferir a propriedade do titulo; e, impropriamente, conferir mandato.

Instituiu a lei nova, em verdade, o endosso pignoraticio. Mas, em face dela, $p$ ara a sua validade, é formalidade substancial seja lançada a clausula de penhor ou garantia. Desta clausula resulta ele e o endossatario se converte em credor pignoraticio do endossador.

Se, porém, ao tempo da lei anterior, não podia o conhecimento ser caucionado sem que, no endosso, se lançasse a clausula sacramental do penhor, porque a lei desconhecia essa especie de endosso; mas se a lei nova, admitindo-o, exigiu como de sua substancia tal clausula, como dar mais valimento, a pretexto de retroagir a lei, ao conhecimento endossado naquele regimen, do que o endossado no atual?

$\mathrm{O}$ decreto - com acerto o decidiu a Quarta Camara do Tribunal de Justiça de São Paulo, por acórdão de 28 de setembro de 1931 - "não se aplica retroativamente a endossos anteriores á sua vigencia. Não tem semelhante alcance o disposto em seu art. 11, $\S$ uniço, que não cuida de dar validade a contratos nulos pela legislação que o precedeu. Entretanto, o mesmo decreto só admitte a clausula de penhor ou garantia quando expressa; e tal não ocorreu com os conhecimentos em questão, nos quais não se nota clausula alguma expressa a respeito" (24).

(24) Diario da Justiça, de S. Paulo, de 7 de outubro de 1931, ano I, n. 214, pag. 10 . 
E reafirmou, dias depois, por acórdão de 22 de outubro de 1931, o seu ponto de vista:

"Mesmo que se aplicasse á especie o decr. n. 19.473, de 10 de dezembro de 1930, (cousa que se não póde fazer porque ele é posterior aos negocios ora examinados), ainda assim se chegaria á conclusão de que não existe garantia pignoraticia, porque, para que esta surja, aquele decreto exige lançamento, no endosso, de clausula de penhor ou garantia".

Eis o sentido do texto.

$\mathrm{O}$ decreto ditatorial reconheceu e assegurou o diretto adquirido.

W A L DEMAR FERREIRA

Professor catedratico de direito comercial. 